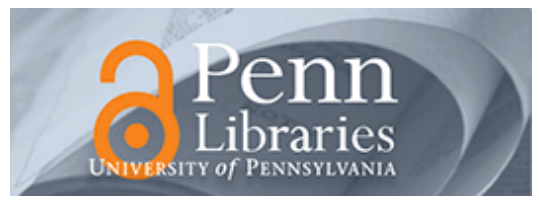

University of Pennsylvania

ScholarlyCommons

Management Papers

Wharton Faculty Research

$9-2016$

\title{
Agency, Structure, and the Dominance of OEMs: Change and Stability in the Automotive Sector
}

Michael G. Jacobides

University of Pennsylvania

John Paul MacDuffie

University of Pennsylvania

Jennifer Tae

University of Bath

Follow this and additional works at: https://repository.upenn.edu/mgmt_papers

Part of the Management Sciences and Quantitative Methods Commons

\section{Recommended Citation}

Jacobides, M. G., MacDuffie, J., \& Tae, J. (2016). Agency, Structure, and the Dominance of OEMs: Change and Stability in the Automotive Sector. Strategic Management Journal, 37 (9), 1942-1967.

http://dx.doi.org/10.1002/smj.2426

This paper is posted at ScholarlyCommons. https://repository.upenn.edu/mgmt_papers/209

For more information, please contact repository@pobox.upenn.edu. 


\title{
Agency, Structure, and the Dominance of OEMs: Change and Stability in the Automotive Sector
}

\begin{abstract}
Research summary: This article reviews structural change in the automotive sector from 1997 to 2007. We find that, following internal framing contests, Original Equipment Manufacturers (OEMs) led efforts to change their sector's architecture, starting from both strong and weak competitive positions and working with suppliers to advocate a new vision based on modularity and outsourcing. As the risks and costs of this vision became apparent, OEMs were able to reverse course and reaffirm their hierarchical control on the sector, taking advantage of structural features that weren't salient ex ante. We consider why certain OEMs initiated this status-quo challenging change, and identify how sector structure mediated their (and suppliers') efforts to implement it. We document the complex change process, driven by agency, structure, and heterogeneity in firms' understanding of their sector's architecture.

Managerial summary: We study the "industry architecture" (i.e., division of labor and profit) of the automotive sector. During the late 1990s, Original Equipment Manufacturers (OEMs) embraced a new vision, based on "Modularity + Outsourcing," inspired by an analogy with Personal Computers (PCs). This seems puzzling since such a change was hard to implement and could have led to OEMs relinquishing strategic control of the sector. The misstep was caused by internal framing contests and the agendas and influence of suppliers, consultants, and academics. We also consider why OEMs were able to partially reverse these changes, and document the role of structural features that let them control their sector and retain value: managing the customer experience, acting as guarantors of quality, and preserving hierarchical supply chains in which they functioned as system integrators.
\end{abstract}

\section{Keywords}

Industry architecture, agency, framing contests, value dynamics, modularity, outsourcing

Disciplines

Management Sciences and Quantitative Methods 


\section{Agency, Structure, and the Dominance of OEMs:}

\section{Change and Stability in the Automotive Sector}

Michael G. Jacobides, London Business School

Regent's Park, Sussex Place, London NW1 4SA, UK +44 2070008716 mjacobides@london.edu

John Paul MacDuffie, The Wharton School, University of Pennsylvania Suite 2000 SH-DH, 3620 Locust Walk, Philadelphia PA, +1 2158980700

macduffie@wharton.upenn.edu

C. Jennifer Tae, School of Management, University of Bath

Claverton Down, Bath BA2 7AY, UK, +44 1225304216

c.w.tae@bath.ac.uk

Running head: Agency, Structure, and the Dominance of OEMs

Keywords: Industry architecture, agency, framing contests, value dynamics, modularity and outsourcing 


\section{Research abstract}

This paper reviews structural change in the automotive sector from 1997-2007. We find that, following internal framing contests, OEMs led efforts to change their sector's architecture, starting from both strong and weak competitive positions and working with suppliers to advocate a new vision based on modularity and outsourcing. As the risks and costs of this vision became apparent, OEMs were able to reverse course and reaffirm their hierarchical control on the sector, taking advantage of structural features that weren't salient ex ante. We consider why certain agents initiated this status-quo challenging change, and identify how sector structure moderated their (and suppliers') efforts to implement it. We document the complex change process, driven by agency, structure, and heterogeneity in firms' understanding of their sector's architecture.

\section{Managerial abstract}

We study the 'industry architecture' (i.e. division of labor and profit) of the automobile sector. During the late 1990s, OEMs embraced a new vision, based on 'Modularity + Outsourcing,' inspired by an analogy with PCs. This seems puzzling, since such a change was hard to implement and could have led to OEMs relinquishing strategic control of the sector. The misstep was caused by internal framing contests and the agendas and influence of suppliers, consultants, and academics. We also consider why OEMs were able to partially reverse these changes, and document the role of structural features that let them control their sector and retain value: managing the customer experience, acting as guarantors of quality, and preserving hierarchical supply chains in which they functioned as system integrators. 
As sectors become increasingly dynamic and interdependent (Adner, 2012; Iansiti and Levien, 2004), our knowledge of industry change is lagging behind reality. In particular, we know relatively little of how industry architecture (IA), in terms of 'who does what,' shapes the division of profit, or 'who takes what' (Jacobides, Knudsen and Augier, 2006). As Ozcan and Santos (2014) and Gurses and Ozcan (2014) have shown, sectors are contested arenas where different participants push their own ideas of what the IA should be. But who actually drives changes in IA — and what enables or hinders such change?

Economics-based research has looked at the evolution of products, markets, and technologies (e.g. Klepper, 1997) rather than the division of labor. Some evolutionary or institutional economists (e.g., Jacobides and Winter, 2005; Langlois and Robertson, 1995) have explored how the division of labor and interactions in a sector develop, but without focusing on how different parties initiate change, or respond to it. Studies rooted in sociology, which consider 'institutional fields' (e.g. Fligstein, 2001; Lounsbury, 2007; Lounsbury and Rao, 2004), have studied mechanisms of change, positing that changes come from fringe actors, and social mechanisms that oblige the dominant actors to change the way work is structured (Leblebici et al., 1991).

More recent work on institutional entrepreneurship (e.g. Henfridsson and Yoo, 2013) has identified the role of exogenous disruptions (e.g., Sine and David, 2003, on the electricity market), emphasizing the power of dominant actors. The strategy literature is more accommodating on the role of dominant actors in sectoral change, with many emphasizing incumbent conservatism or inertia (Benner, 2010; McGrath, 2001; Miller and Chen, 1994; van Wijk et al., 2013; Zirger and Maidique, 1990). Others consider the facilitative role of incumbents (Jacobides, 2005; Song and Parry, 1997; Tripsas, 1997). That said, there is limited coverage of the question of who initiates change, especially as it relates to IA, and how this change process unfolds. This is the research gap we aim to fill. 
Our study focuses on the automotive sector, which is one of the largest industrial sectors worldwide, with an important share of GDP and employment in the G7 countries. Since one of the authors had researched this sector over the last three decades, with first-hand involvement in projects examining the division of labor and terms of engagement, we were able to draw upon qualitative field-based interview data collected at the time of the events under examination, unaffected by attribution bias (Ross, 1977). Sector familiarity allowed us to supplement this historical evidence with additional interviews (conducted between 2012 and 2013), archival data, and industry statistics to triangulate our evidence.

We find that car manufacturers (often termed 'Original Equipment Manufacturers (OEMs)' and including firms such as Chrysler, Fiat, Ford, and Hyundai) have played the key role in efforts to transform their sector. Far from being conservative, status-quo-antesupporting incumbents with organizational inertia (Hannan and Freeman, 1984), they instead launched sector-change initiatives that used a compelling vision of the future architecture to enlist the cooperation of those with divergent interests.

The dominant analogy influencing the automotive industry during our data collection was the transformation of the vertically integrated computer sector to a vertically unbundled and modular, as opposed to hierarchical, structure. Hoping to emulate this, automotive OEMs tried to shed assets, outsource to invest more in downstream customer services, and push for a more modular product and industry architecture. These initiatives towards a strategic vision of 'Modularity+Outsourcing $(\mathrm{M}+\mathrm{O})$ ' in the late 1990s and early 2000s, represents a theoretical puzzle since it both failed to deliver the anticipated benefits, and risked shifting strategic control to suppliers (MacDuffie, 2013).

This gave rise to the second process of IA change we observe by the mid-2000s, whereby OEMs managed to reverse or modify many of the changes they had instigated, dropping the ' $\mathrm{M}$ (modularity)' from $\mathrm{M}+\mathrm{O}$ and keeping the ' $\mathrm{O}$ (outsourcing).' Our study thus 
also sheds light on why, in this setting, OEMs could reassert dominance over their industryunlike computers, where the change to a modular structure could not be reversed, despite computer assemblers' best efforts. Our primary interest isn't 'how much' change took place, but rather the interplay of agency and structure: who initiated change, and which structural features caused their change efforts to be modified, and partly abandoned.

As well as uncovering OEMs' motives and internal decision dynamics, we highlight the frames and analogies that built a shared future vision among OEMs and their core suppliers (called 'Tier 1s' to differentiate them from lower-down 'Tier 2' and 'Tier 3' firms, who interact primarily with the tier above). We look at the evolution of OEMs as a group, but also the individual firms at the forefront of change: Chrysler, Fiat, Ford, and Hyundai. We unpack their idiosyncrasies as firms, but we also open up the 'black box' and see which groups within OEMs sponsored (or challenged) these changes. We also consider how heterogeneous groups converged on analogies that turned out to be misguided.

Specifically, we explore how, within OEMs, the new vision of the sector won out against internal resistance. We also show how change advocates found common ground with like-minded enthusiasts within Tier 1s who were seeking to capture more value-added tasks and drive up margins via greater autonomy. While skeptical voices at the OEMs were drowned out by the initial excitement, they did influence internal debates. Indeed, as skeptics gained ground, suppliers were left protesting that OEMs were abandoning the earlier vision.

Our analysis thus also helps address the puzzle that would emerge if we were to look at the evolution of scope in the automotive sector from a Transaction Cost Economics (TCE) perspective. OEMs ended up sourcing modules from the suppliers through markets, without a full consideration of the potential contractual hazards that this would entail. ${ }^{1}$ Our account

\footnotetext{
${ }^{1}$ The adoption of the term 'module' and the boundary definitions of the initial automotive modules (e.g. seats, the instrument panel, and front end) occurred around production goals (i.e. 'modularity for production'). From the point of view of 'modularity for design,' however, these automotive 'modules' rarely possessed the classic characteristics defined in the operations and strategy literature based on products such as the personal computer
} 
explains why OEMs, who did call the shots in terms of organizing their own internal operations and supply chain, undertook what was ex ante, a transactionally risky approach. We do so by looking at the way decisions were made within OEMs, and at how the 'vision' for the sector temporarily blinded some (but not all) actors to the potential hazards.

We also consider what allowed OEMs, who had proactively advocated the new structure, to row back. In sharp contrast to computers, where outsourcing led to vertical unbundling by creating a set of modular, open-access segments, automobiles were still produced through a hierarchically managed supply chain. OEMs did allocate design and production tasks to specialized suppliers of components, but because they maintained proprietary component designs, they were able to shape their IA.

This hierarchical approach to outsourcing proprietary components reinforced (rather than undermining) the OEMs' system-integrator role - their primary source of control over value creation and capture. OEMs were also able to maintain the locus of differentiability, being the guarantors of quality along the sector. We thus find that these structural attributes do not just affect the ability of OEMs to shape their sector's structure; they also underpin their ability to extract value from it.

To understand OEMs' dominance in value capture, we also look at their influence on sector structure. OEMs' ownership of regulatory accountability and legal liability gave them significant power to discipline the rest of the sector. Their control over the customer experience, compounded by the sector's slow clockspeed, also helped them dominate. Thus, the next part of our analysis looks at why this risky transformation ended up being largely reversed, or rethought, to OEMs' benefit, allowing them to maintain strategic control.

(Ulrich, 1995; Baldwin and Clark, 2000)-i.e., one-to-one mapping of function to component; or being independent across / interdependent within module boundaries. Automotive modules were also OEMproprietary based on closed standards, in contrast with the industry-standardized modules of the computer sector. These characteristics created high asset specificity and coordination complexity once OEMs began outsourcing the design of these already-production-defined modules (MacDuffie, 2013). 
Moving beyond the automotive sector, we think that it is important to better understand how and why dominant actors in an IA may change their sector and their own business model—hastily, and potentially self-destructively. From telecommunications and media to energy and banks, leading firms are often highly proactive in reshaping their sector. Sprint and Nextel-like Time Warner and AOL in an earlier era-are reminders of the perils of over-zealous greenfield and mergers and acquisitions (M\&As) moves to transform IA. We

also need to understand which structural features determine the ability of dominant players to shape their sector, and drive the process of value capture.

\section{THEORETICAL BACKGROUND}

Several research streams have touched on industry transformation, but few have directly analyzed the relationships among actors in an ecosystem. We thus provide a quick overview of research related to our two core research questions: How and why did OEMs change the architecture of their sector? And what features of that IA helped or hindered them?

The broader question of which firms in a sector pursue innovation has been an important area of research in industry evolution. Schumpeter's late work (1950) stressed the role of leading firms in driving the innovation process overall — in contrast with his earlier views (1934), which emphasized the role of entrepreneurial entrants in the process of 'creative destruction.' Subsequent research has looked at size and entry dynamics, in considering the engine of innovation (see, e.g., Audretsch, 1995), and engendered the literature on 'entrepreneurial regimes' — one of which is dominated by dynamic entrants, the other by established firms (see Breschi, Malerba, and Orsenigo, 2000). This literature, though, while broader, does not address our question. It follows the norm of industry evolution studies that do not consider sectoral innovations either in terms of vertical structure or the patterns of labor and profit division in IAs, which is our focus.

From an economics-based perspective, students of industry evolution (Geroski, 2005; Klepper, 1997; Nelson and Winter, 1982) have undertaken and inspired substantial research on how, on the aggregate, sectors, markets, or technologies evolve. However, research on how the division of labor within a sector evolves has been much more limited. Within this 
narrower literature (see Langlois and Robertson, 1995, Jacobides and Winter, 2005), the focus has been on how sectors generally evolve, and new intermediate markets emerge (Langlois, 1992; Jacobides, 2005). There has also been considerable study of the evolution of life-cycles and sub-markets (Klepper, 1997; Klepper and Simons, 2000), and of technologies (Dosi, 1982; Tushman and Anderson, 1986). However, even when relationships along the value chain are considered, little work has analyzed the agency for change, the features that enable or constrain changes in structure, or changes in value distribution at the sector level.

The literature that addresses changes in scope, of course, is transaction cost economics (TCE) (Williamson, 1985, 1996). TCE focuses on individual transactions, and explains the way in which firms build their transactional choices as a function of the attributes of the transaction at hand (Monteverde and Teece, 1982). This choice can be also influenced by their history (Argyres and Liebeskind, 1999), their capabilities (Jacobides and Winter, 2005), and/or contractual tools. One could extrapolate this transaction-level approach to look at general changes in scope in a sector to explore aggregate patterns. Thus, as Argyres and Bigelow (2010) argue, if greater modularization and standardization emerge as a sector matures, then transactional risks are mitigated, and we would expect greater dis-integration, such as that seen in the early stages of the automobile industry. Langlois and Robertson (1989), also drawing on early automotive history, posit that as suppliers in a sector become more capable, dis-integration can emerge. Their emphasis is on 'dynamic' transaction costs, which include changes over time in scale of production, appropriability, and demand.

Our analysis considers the contractual hazards involved in the changes automotive OEMs undertook, and attests that the changes undertaken were in the opposite direction from what TCE would predict — even though certain executives within firms were rightly pointing to these risks. This may partly explain why these changes were later abandoned. Moving beyond the 'economizing logic' and the 'discriminating alignment' between transactions and the governance mode that is chosen at each transactional juncture, we are also interested in the strategic considerations that shape firms' views in terms of their sector, and look within firms to understand the factors shaping their choices. 
To do so, we draw on the literature on 'industry architectures,' which has focused explicitly on how firms try to shape their sectors (Jacobides et al., 2006) and capture more value (Pisano and Teece, 2007). These efforts, IA research suggests, are driven not only by the capabilities of the sectors' participants (Jacobides and Winter, 2005; Langlois and Robertson, 1995), or transactional features (Argyres and Bigelow, 2010; Williamson, 1985), but also by their interests in terms of value capture. IA thus reflects the strategic struggle to define the terms of engagement and shape the sector itself. Ferraro and Gurses (2009) show how Lew Wasserman, Chairman of the Music Corporation of America (MCA), used new technology to change the institution of the entertainment industry and benefit his own firm. To affect the IA, firms try to become 'bottlenecks' (Baldwin, 2015) by taking up positions that give them control over scarce resources or outputs, power over peers and, as a result, better opportunities for value capture, as Fixson and Park (2008) show for Shimano in the bicycle industry. Leading firms sometimes push for their entire segment (themselves, plus a few competitors) to become a bottleneck, as Jacobides and Tae (2015) show for the computer sector. However, research to date has not focused on industry change or the structural features that affect it. ${ }^{2}$

Since firms use ideas and imagery to promote their own sectoral vision, one might expect significant mileage from the recent interest in cognition and frames (Eggers and Kaplan, 2013; Kaplan 2011). Yet while considerable research has emerged on competing frames (Kaplan, 2008), most of it is at the level of the firm, not the sector. While cognitive differences and heterogeneity in frames and mental maps have been marshaled to explain firm-level performance heterogeneity (Gavetti, 2012; Gavetti and Levinthal, 2000), much less attention has been paid to framing contests between participants along an ecosystem. So, while Porac, Thomas, and Baden-Fuller $(1989,2011)$ have shown that a sector may be blindsided by its own conception of reality, the way in which these views are collectively

\footnotetext{
${ }^{2}$ In new and nascent markets, research has identified the strategic importance of shaping the environment, which then defines the rules and roles that pertain to the division of labor and IA. Santos and Eisenhardt (2009), for instance, describe the process through which entrepreneurial firms try to mold the environment to suit their interest. Conversely, if it is not possible to establish rules on the division of labor in an emerging field, new products or services may fail to 'take root,' as Ozcan and Santos (2014) show for the case of mobile payments.
} 
formed or disrupted has not been explored. ${ }^{3}$ This is particularly puzzling, since Ng, Westgren, and Sonka (2009) have shown that visions of reality differ between parts of the value chain.

Thus, we still lack a clear sense of how different actors - whether leaders or laggards, dominant or subordinate - wage the battle of ideas over their sector's future.

Finally, our study builds on and extends research that has examined both structure and value creation and capture in the automobile sector ${ }^{4}$ by considering the endogenous drivers of the sectoral transformation of the 1990s and 2000s.

Our study draws on archival material and contemporaneous interviews, supported by industry data, to examine our two central research questions: (1) Why did the automotive industry become so smitten with the M+O vision in the late 1990 s, so as to try to change its IA? Who drove this change, what was their motive and how did they try to advance their cause? (2) What IA features determined the evolution of value-chain structure and value capture? Specifically, what allowed OEMs to row back on their changes and change the division of labor without altering the division of profit?

\section{DATA AND METHODS}

Our data are collected from archival and qualitative sources and informed by quantitative data and discussions within a multi-researcher team. The level of analysis is the entire industry / sector architecture or value chain ${ }^{5}$ and the scope of the research is global. The research design relies on comparative cases at the firm level, including both OEMs and Tier $1 \mathrm{~s}$, in order to draw inductive conclusions about industry-level phenomena. The

\footnotetext{
${ }^{3}$ A recent exception is Gurses and Ozcan (2014), who show how different participants, and especially aspiring entrants, have tried to shake the status quo, legitimizing their own version of an IA and co-opting key industry players, regulators, and the public. Yet in this paper, as often elsewhere, established actors are seen as trying to fend off entrants and defend the status quo.

${ }^{4}$ The book The Machine That Changed the World (Womack, Jones, and Roos, 1990) explored the Toyotainfluenced Japanese production paradigm, including more collaborative ways of organizing the supply chain (Dyer, 1996; Helper and Sako, 1992; Pil and MacDuffie, 2000). Studies such as McMillan (1990), Asanuma and Kikutani (1992), and Nishiguchi (1994) examined the economic logic of such arrangements, and explored how the leading firms discipline their suppliers as well as how joint value is produced (Cusumano and Takeishi, 1991; Dyer and Ouchi, 1993). However, the juxtaposition of the American and Japanese systems (Taylor and Wiggins, 1997), or the discussion of how Western (mostly U.S.) companies emulate the Toyota Production System (e.g. Kenney and Florida, 1993), told us little about sector dynamics, whether in a single country or globally (Gereffi, Sturgeon, and Humphrey, 2005).

5 'Value chain' refers to the vertical segments. In automotive sector, this includes Research and Development (R\&D), product development, manufacturing, upstream supply chains, and downstream distribution channels.
} 
longitudinal analysis of change initiatives undertaken by proactive OEMs and Tier $1 \mathrm{~s}$, our primary focus, is based on multi-method evidence from the historical record and collected in the field. Tables A1 and A2 summarize these data sources. ${ }^{6}$

Specifically, our research relies primarily on data from a project in which the second author, with colleagues from the International Motor Vehicle Program (IMVP), examined whether the global automotive industry was undergoing a fundamental restructuring that would shift power from OEMs to suppliers. Data were collected from 1997 to 2007 (mostly between 1998 and 2003) by a team of researchers in seven countries via semi-structured interviews with executives, managers, and engineers at OEMs and suppliers. Rather than trace the value chain from one OEM to its entire set of upstream suppliers, this team pursued data from a range of OEMs and suppliers undertaking substantial $\mathrm{M}+\mathrm{O}$ initiatives, regardless of the relationship among them. Original notes from this project capture perspectives of the time, and as such are unaffected by ex post facto rationalization.

The nine OEMs in this study comprise: the U.S. 'Big Three' of GM, Ford, and Chrysler; Fiat, Renault, and Volvo in Europe; Hyundai in Korea; and Nissan and Toyota in Japan. Our interviews also covered GM's and Ford's substantial activities in Europe. Our sample therefore includes the largest OEMs in the global automotive industry, with the exception of the Volkswagen group (VW) in Germany. Tier 1 suppliers in our sample include many of the largest automotive suppliers in North America, Europe (Italy, France, Germany), Japan, and Korea. Some of these firms have close ties historically to a single OEM (e.g. Denso with Toyota; Calsonic Kansei with Nissan; Magnetti Marelli with Fiat; Sommer Allibert with Renault) and some are spinoffs of parts subsidiaries from their parent companies (e.g. Delphi from GM; Visteon from Ford; Mobis from Hyundai). Nevertheless, they were all global suppliers during the period of our study, and all provided components to multiple OEMs in multiple regions.

Beginning in June 2012, we further developed and extended our analytic framework with 22 additional interviews with knowledgeable industry participants and analysts. ${ }^{7} \mathrm{We}$

\footnotetext{
${ }^{6}$ All Tables and Figures labeled with an 'A' (e.g. Table A1, Figure A1) are available in the online appendix.
} 
started with open-ended questions about their observations and attributions vis-à-vis restructuring for the global automotive industry, and then asked follow-up questions to understand their view of the underlying dynamics of industry evolution, as well as their expectations for future industry structure and competitive dynamics. These more recent interviews were supplemental to our earlier data collection, and we always subordinated them to the contemporaneous accounts; nonetheless, they add valuable nuance to our analysis.

Working inductively from our field data, we present the causal relations derived along with the evidence, so the reader can evaluate our inferences (Yin, 1994). Instead of offering a qualitative snapshot that summarizes participants' sense-making (Walsh, 1967), we provide a longitudinal analysis comprising both facts and the narratives created around them. The 2012-13 interviews helped reduce bias through the combination of retrospective analysis and prospective questions (Huber and Power, 1985; Leonard-Barton, 1990), providing triangulation and confirmability from diverse sources (Guba and Lincoln, 1982). Overall, we relied heavily on data and evidence from the historical record, which enabled us to identify a complementary set of causal factors (Kieser, 1994: 618). Our approach yields insights based on our inductive understanding of 'process' as opposed to 'variance,' following Mohr (1982), and is rooted in historical evidence (in the spirit of Skocpol, 1984).

Insert Figures 1 and 2 about here.

\section{EVIDENCE AND RESULTS}

In keeping with our method, we offer a conceptualization (see Figure 1) of how agency and structure interacted to yield change and stability in the automotive sector over approximately a decade (1997-2007).

Figure 1 provides a process diagram of IA change, and corresponds to the way we analyze the evidence. First, we consider why and how key agents, under external competitive pressure during the early 1990s and confronting internal challenges, framed their interests in

\footnotetext{
${ }^{7}$ Our 22 interview subjects in 2012-13 included two Federal Reserve Bank economists; two automotive industry historians; one U.S. government automotive industry analyst; one Canadian government automotive industry analyst; four senior executives from OEMs; six senior executives from Tier 1s; one senior official from a supplier association; two automotive industry consultants; and three financial/stock market analysts. Interviews lasted from 45 to 120 minutes. Quotes from these subjects are identified in both text and tables.
} 
new ways. This reframing prompted a search for strategic initiatives that could resolve internal problems and improve performance. Framing contests took place both within firms (where a coalition for change was needed) and across firms (where interdependence made it necessary to align interests). Second, we examine two iterations of strategic initiatives: the first during the mid-to-late 1990s, when OEMs and Tier 1s jointly pursued a new, vertically unbundled sector architecture, and the second during the early-to-mid 2000s, when OEMs backed away from modularity while retaining outsourcing, thus maintaining their hierarchical supplier structures. Third, we explore how the powerful channeling effect of the existing sectoral architecture mediated the effects of these strategic initiatives, and the resultant consequences for change and stability by the mid 2000s. Fourth, we evaluate whether these developments affected the distribution of value and the likelihood of future value migration.

\section{The structure of the automotive industry}

This section sets the stage with an explanation of context. (Note that it is based primarily on the U.S., where the mass-production automotive industry first emerged.)

Historically, the automotive industry's key structural characteristics were vertical integration, capital intensity, and economies of scale (see Table A3). The early 1900s saw many competing firms and product concepts. Once a dominant design was reached (circa 1927), tremendous consolidation took place during the 1930s, leaving a few OEMs that amassed crucial system-integration capabilities and massive scale, deterring new entrants. To this day, OEMs do most R\&D, develop product architecture, design specific models, and set (mostly proprietary) specifications for components. Initially, components were manufactured within OEMs, but were outsourced to suppliers over time. From the outset, proprietary (closed) designs have meant that suppliers have been under tight hierarchical control, requiring them to make asset-specific investments for each OEM customer. OEMs are also skilled at setting up competitive bidding for high-volume contracts — attractive for a supplier to win, but with an ever-present risk of being undercut on price. While OEMs can benefit from long-term relationships with suppliers, given the asset specificity associated with many outsourced components, they often choose to exercise their high-volume purchasing power 
by frequently switching suppliers - or at least threatening to do so (Helper, 1991) as a means of maintaining control.

OEMs control final assembly, where system-integration capabilities (see Prencipe, Davies, and Hobday, 2005) as well as scale economies are crucial. They then distribute finished vehicles to dealerships for sale to consumers. Dealerships are separately owned franchisees that contract with OEMs to represent the brand, sell the vehicles, and provide maintenance and repair services to consumers. OEMs control the brand, dominate marketing activities, and shape dealership sales via incentives.

Furthermore, OEMs face regulatory requirements to certify vehicle characteristics and performance, and shoulder most legal liability. They must validate components from suppliers, under historical precedent that the final assembler is responsible for product defects or failures, and are responsible (in consultation with regulators) for initiating product recalls. Automobiles are large, heavy, fast-moving machines operating in public space (MacDuffie and Fujimoto, 2010), which creates a particular set of public policy issues: safety, fuel efficiency, emissions, etc. This drives the regulatory parameters confronting OEMs. While the regulatory/legal responses to these issues do vary by country, most developed countries, at some point, give OEMs primary legal and regulatory responsibility; developing countries follow suit as their level of motorization increases. Thus all OEMs that wish to compete globally must achieve a similarly high level of system-integration capability.

U.S. OEMs were highly vertically integrated from Henry Ford (beginning in 1910) onwards - more so than those in any other country. Japan represents the other end of the spectrum. During the post-WWII period, the multiple OEMs competing in the small Japanese domestic market learned to design a full portfolio of vehicles and manufacture in small batches, which required the development and mastery of flexible production techniques for rapid changeover. Rather than vertically integrate component manufacturing, Japanese OEMs chose to rely on suppliers. ${ }^{8}$ European OEMs were, throughout their history, less vertically

\footnotetext{
${ }^{8}$ These suppliers were typically organized in a hierarchy with Tier 1 overseeing Tier 2, Tier 2 overseeing Tier 3 , and so on (Nishiguchi, 1994). OEMs took an equity stake in these suppliers, who were generally captive (i.e. only one customer), making them members of the OEM's keiretsu, or group of interlocking companies.
} 
integrated than U.S. OEMs and had a tradition of relying more on suppliers for design support, while Korean OEMs (established in the 1960s) were closer to the Japanese model, with supplier companies linked to large corporate chaebol.

During the postwar period and through the 1970s, this national/regional heterogeneity persisted, with the structure of each OEM's supplier relationships being relatively stable due to dyadic relationships and proprietary (closed) design specifications for components. Global competitive pressures in the 1980s and 1990s would change that.

\section{The context before sectoral change: Dynamics in automobiles in the 1980s and 1990s}

During the 1980s and 1990s, global automotive OEMs and their Tier 1s faced the rise of the Toyota Production System (TPS), also known as 'lean production.’ TPS presented an alternative paradigm to mass production, with a different logic for organizing the sector, from product development and process engineering to purchasing and manufacturing. The approach was best exemplified by Toyota and its keiretsu suppliers, but had also been mastered by other Japanese OEMs and was diffusing via the globalization of those firms.

TPS posed tremendous competitive challenges for U.S. and European OEMs. Performance gaps manifested in both productivity and quality metrics for manufacturing (lean plants had lower labor hours and fewer defects) and for product development (lean firms had lower engineering hours and fewer months from start of design to product launch). There were also different philosophies of process engineering (TPS uses 'pull' rather than 'push' process flow and is less reliant on automation); and supply chains marked by close coordination with suppliers to keep inventories low through kanban pull-based replenishment signals and 'just in time' delivery, plus collaborative efforts during component design.

Following protracted attempts to implement TPS, many U.S. and European OEMsand the analysts monitoring their performance - felt their progress in closing the performance

Suppliers worked closely with their keiretsu OEM on design and production improvements, typically following OEM design specifications under close direction. 
gap was too slow. The Harbour Report, launched in the early 1990s by a consulting firm that benchmarked assembly-plant productivity, pressured them to reduce hours per vehicle, while J.D. Power surveys of consumer-perceived quality (initiated in the 1980s) did the same for defect reduction. ${ }^{9}$ Surveys of supplier relations pointed out low trust between OEMs and Tier $1 \mathrm{~s}$, making the close coordination necessary for TPS challenging. OEMs that developed and launched vehicles more quickly gained market share, creating urgency about shortening product cycles. Finally, at the corporate level, the profitability of many OEMs rose and fell with the business cycle, but performance on metrics such as return on assets (ROA) stayed consistently lower than most other industries. OEMs' asset-laden balance sheets confirmed their 'heavy industry' image in investors' eyes, impairing their ability to attract capital.

Figure 2 provides a historical overview of the main structural changes in the automotive sector in the period we focus on. We note the main trends in the sector in black, and our deduced causal relations in blue. Figure 2 suggests that pressures on OEMs motivated a number of change initiatives, consistent with what the Behavioral Theory of the Firm (hereafter BTOF) (Cyert and March, 1963) would predict: Firms that were challenged engaged in a quest for innovation. Those change initiatives, though, were not focused on emulating successful competitors' internal practices such as TPS. Rather, U.S. and European OEMs took the lead in proposing sectoral changes that were quite distinct from TPS and focused on rethinking the sector structure. Building on small-scale experiments in manufacturing, they expanded their ambitions to a strategic vision of a modular and deverticalized structure in which suppliers would take on significant design responsibilities. The model for change was the computer sector, due to its rapid growth, fast pace of

\footnotetext{
${ }^{9}$ The annual Harbour Report on assembly plant productivity was not publicly available but was sold to industry analysts as well as OEMs; press coverage of each year's results was typically based on analyst interviews. In contrast, the annual J.D. Power Initial Quality Survey on assembly plant quality was released publicly with aggregate results at the brand level (e.g. Ford, Toyota), with plant-specific details only available to purchasers of the full report. OEMs thus had access to these benchmarking data at the level of specificity that wasn't visible to the public. Relatedly, we can't provide a citation to those detailed reports.
} 
innovation, and high performance on both technological and financial criteria. Using computer sector as proof positive, OEM-based advocates could enlist Tier 1s by promising them a larger role than ever before.

Third-party experts (e.g. financial analysts, consultants, and academics) were only too willing to endorse this approach. With complexity and coordination costs rising from product proliferation, inter-organizational alliances, and global expansion, they promoted models of industry structure that reduced interdependence through modularity and outsourcing.

The concepts of modularity and outsourcing are distinct, and the actors did not link them right away. In principle, modular architecture can reduce complexity, offering the potential for speedier innovation (any design improvements are possible as long as interface standards are met); shorter product development lead times (by minimizing coordination requirements); and customization (by allowing modules to be mixed and matched, Legostyle, to deliver customer-specific functionality). ${ }^{10}$ In principle, outsourcing is a way to lower costs and reduce complexity by shifting tasks to a specialized supplier that can achieve efficiencies through focus and access to lower-priced inputs. OEMs, in particular, were drawn to both concepts based on these anticipated benefits.

For a time, the initiatives were separated, both conceptually and functionally, with outsourcing driven by purchasing and modularity by manufacturing. It was only when a strategic vision of modularity + outsourcing ('M+O') emerged that advocates could posit a transformed IA based on alignment of OEM and supplier interests. This vision of a new IA eventually permeated not only relationships along the automotive ecosystem but also the capital and debt markets. What its advocates neglected to point out, though, is that the $\mathrm{M}+\mathrm{O}$

\footnotetext{
${ }^{10}$ As noted above, in the automotive industry 'modules' were understood as physical bundles (e.g., instrument panel (cockpit) 'module'), denoting a different interpretation to that given by the modularity literature (see MacDuffie, 2013), which altered the prospects of achieving these benefits.
} 
combination is precisely what caused computer OEMs to lose both power and their share of value capture to specialized suppliers of key modules (Jacobides and MacDuffie, 2013).

\section{A Shift in How Agents Frame Their Interests: How OEM-Supplier Consensus Emerged}

Outsourcing in the automotive industry had featured since the industry's inception, as noted in Table A3. By the 1980s, mindful of the Japanese example and with new options to source components in low-wage countries, U.S. and European OEMs increasingly outsourced. The initiatives of the late 1990s accelerated the trend considerably, as discussed below.

In contrast, the interest in modularity was a novel development, applying initially only to manufacturing. Fiat, for example, approached modularity initially as an internal initiative in the 1980 s tied to the joint design of a new product and a new assembly plant. To increase automation (reducing direct labor), it was advantageous to install a smaller number of large subassemblies, rather than using the traditional 'layer build,' in which a large number of small parts and components were installed on the assembly line. At first, these subassemblies (soon termed 'modules') were built on separate lines inside the new Fiat factory; another advantage was that each module could be tested for quality defects before being installed in the vehicle. Outsourcing of modules began in the 1990s; having physically separated the production task from the assembly line, it soon became apparent that the task could be passed to a specialized supplier with lower labor costs.

On the other hand, Ford was initially focused on outsourcing as a means of drawing on the specialized component competence of suppliers to reduce the cost and complexity of its assembly plants. Starting in Europe in the mid-1990s and continuing in Brazil, outsourcing at Ford was paired with goals for reducing inventories via 'supplier parks,' at which suppliers would locate close to the Ford assembly plant to shorten delivery time (Sako, 2009). This approach made the most sense for large, heavy subassemblies containing parts that varied based on customer preferences, e.g. seats, the instrument panel (cockpit), and vehicle front ends; these also became known as 'modules' after outsourcing began. 
These early manufacturing initiatives had a narrow scope and limited impact on structural characteristics, ${ }^{11}$ and OEMs soon came to view the resulting gains as too limited. While outsourcing larger chunks might lead to some cost savings, OEM executives were concerned not only with contractual risks, but also with overall supplier capability to meet cost, quality, and delivery goals. Yet modularity advocates shifted their attention, arguing that OEMs could reduce the cost and complexity of product development by drawing on suppliers' component expertise for module design. Suppliers had been asking for more design responsibility for years, but OEMs were typically not interested. So why did these arguments suddenly appeal to them, particularly to their senior executives?

Recall that by the mid-1990s, OEMs were facing increasing global competitive pressure, plus criticism from financial analysts. Meanwhile, consultants and academics were touting the latest strategy ideas and analogies from other industries. All this made $\mathrm{M}+\mathrm{O}$ very appealing. If suppliers could take over both design and manufacturing of complex subassemblies that constituted a large part of the vehicle's value, this would improve OEM labor productivity, improve OEM ROA, reduce OEM design work, reduce the complexity of OEM product development and manufacturing, and, most importantly from a strategy point of view, allow both OEMs and suppliers to focus on their respective 'core competence.'

Chrysler was another OEM that implemented these initiatives in the 1990s, prompted by competitive difficulties in the 1980s that caused layoffs of staff in product and process engineering. Like Fiat, they embraced $\mathrm{M}+\mathrm{O}$ because they no longer had the expertise internally. According to one Ford respondent, "Chrysler had to go to modules because they lost all of their people and have to rely on their suppliers." This acknowledges the potential for a shift of power from OEM to supplier, albeit when OEM engineering capabilities were already weak. The change dynamic had begun.

\footnotetext{
${ }^{11}$ Here too, the definition of automotive modules differed from computer modules in important regards. From the perspective of the functional specialists dealing with manufacturing and purchasing decisions, automotive 'modules' were, in a sense, merely new terminology for the large subassemblies that were subject to the same 'make vs. buy' decisions as all components.
} 
What ultimately bolstered the credibility of $\mathrm{M}+\mathrm{O}$ was the proactive pursuit of the vision by OEMs such as Ford, GM, and up-and-comer Hyundai. Ford, in particular, saw it as a way to focus on new business models - most notably downstream consumer services that would boost its share of customer interactions and expenditures after the sale. ${ }^{12}$ The dominant narrative at Ford in the late 1990s was one of choice rather than necessity, emphasizing a new division of labor based on a more rational focus on 'core competence., 13 At Hyundai, the consolidation of parts subsidiaries into mega-supplier Mobis in 2000, following a broader corporate reorganization, was the trigger for its modularity push.

Given the importance of design in differentiating products and establishing brand identity, why were strong OEMs like Ford suddenly willing to give suppliers more control? This is a key question, because the consequence of such a move in the computer sector was a significant and seemingly irreversible shift in power from OEMs to horizontally specialized suppliers (see Bresnahan and Greenstein, 1999 and Jacobides and Tae, 2015). Why would automotive OEMs risk a similar fate?

The guiding concept of 'core competence' was drawn from Prahalad and Hamel's 1990 article; according to a recent assessment by the Economist (2008), it "spread from core competencies to core everything — core processes, core businesses - everything that constituted the essence of what a company was and did. Management consultants encouraged companies to focus on their core as a source of untapped potential in a time of rapid change and unpredictability."

To allow automotive OEMs to achieve this focus, third parties urged the creation of large 'full-service' suppliers that could handle the design, purchasing, and production of all

\footnotetext{
${ }^{12}$ Chief Executive Officer (CEO) Jac Nasser made headlines by stating that Ford would become a 'consumer services company' rather than being just an automaker (Kerwin and Naugthton, 1999). Accordingly, Ford invested aggressively in downstream consumer services, mostly through acquisitions, e.g. Hertz (100\% owned by 1994, partially spun-off in 1997, reacquired in 2000); Norwich Union (UK) automotive insurance (1998); Kwik-Fit (quick service for oil changes, etc., 1999); Collision Team of America, body shop chain (minority stake in 1998); automotive parts recycling firms Copher Brothers (1999) and Cumberland (2000); and others.

${ }^{13} \mathrm{GM}$ sounded a similar note after successful experiments with a 'modular consortium' in Brazil in the mid1990s, with co-located suppliers who could deliver complex subassemblies on a just-in-time basis (Sako, 2009).
} 
components in a complex subassembly/module. One consultant report explained the responsibilities of a 'full-service' supplier, in an idealized view that shows suppliers taking burdensome tasks away from OEMs without challenging their prerogatives:

The module supplier is expected to provide full services in support of the design, development, manufacture, warranty, and supply of replacement parts for the modules it is supplying. This does not mean that the OEM will give the supplier autonomy in the design of the module, the design process will be a collaborative process with the OEM engineering function in the majority of cases. (Berkt Group, 1998)

During this period (1998-2003), IMVP's Modularity and Outsourcing project attracted many sponsors, allowing researchers to conduct fieldwork at OEMs and Tier 1s worldwide. IMVP always presented 'modularity' and 'outsourcing' as two distinct activities that could be implemented either separately or together. Yet virtually all initiatives (with the exception of Japanese OEMs', e.g. Toyota) combined them into a single strategic vision. ${ }^{14}$

Still, the initiative that made the most headway was the outsourcing of major subassemblies to suppliers and the (mostly) horizontal combination of specialized suppliers in order to meet the increased capabilities demanded by OEMs. What became known as 'mega-suppliers' emerged in multiple ways. Financiers and consultants encouraged the two U.S. OEMs who were still highly vertically integrated to spin off their component part divisions. Both GM and Ford followed their guidance, with GM spinning off Delphi in 1999 and Ford spinning off Visteon in 2000. (Chrysler, although historically the least vertically integrated of the Big Three, had deverticalized in 1987 by spinning off its parts subsidiaries into Acustar, a much smaller firm. ${ }^{15}$ Similar arguments were made to encourage Tier $1 \mathrm{~s}$ to

\footnotetext{
${ }^{14}$ In a rare moment of candor, one Toyota executive, in 1999, made the following comment: "Our competitors will pursue modules and they will have quality problems as a result and our advantage over them will only grow." Our fieldwork suggests that Toyota was not ignoring modularity, but viewed it as something to explore first internally, particularly with respect to design. Toyota was more cautious, experimented within its own boundaries, and didn't subscribe to the new vision—rightly so, as it turned out.

15 These spin-offs didn't create captive groups; indeed, the rationale for their creation was to make the components part of the business less captive, so it would face more competition. The former parents did not have any extraordinary say in the functioning of these firms. When GM announced its plans to make Delphi fully independent in 1999, Delphi's share of non-GM North America business was 34\%; the target goal was to reach $50 \%$ by 2002 . GM ultimately gave away $100 \%$ of its spin-off equity away, not holding any stock; $80 \%$ was distributed to GM shareholders pro-rata and $20 \%$ by IPO. Ford spun off Visteon in 2000, with all shares
} 
undertake horizontal M\&A with each other, e.g. to combine plastics molding firms with seat makers or electronics firms to create mega-suppliers that could bid on instrument panel (cockpit) modules. Finally, in recognition of the increasing importance of electronics and software in automotive systems, some established IT firms, including Microsoft and HP, diversified into the automotive industry.

The net impact was to give outsourcing an apparently irresistible momentum. Indeed, outsourcing initiatives soon outpaced modularity initiatives. Figure A1 shows the drop in the percentage of vertical integration at the Big Three over 1975-2000, in comparison with the persistently low percentage among Japanese OEMs. Figure A2 shows the rise in the number of mega-suppliers from 1992 to 2004.

For some consultants and academics, these changes were portents of disruptive changes in the sector's architecture. According to a Bain \& Company report by Donovan (1999), "The new giant suppliers will quickly move to designing vehicle systems that can be 'standardized' within and across OEMs - in other words, used in multiple models of an OEM and eventually by multiple OEMs." According to some academics, autos would mirror IT: "Chrysler has played the role of the Compaq of the automotive industry. Chrysler's strategy allows suppliers - even Ford's and GM's internal suppliers - to strengthen their capability to develop whole automotive subsystems, thereby pushing the entire structure of the industry from vertical toward horizontal (Fine, 1998, p. 62)." Another academic told us, "Modules will affect the industry structure. When suppliers get more experience and volume, they can begin to dictate design, price, module scope to the OEMs (personal communication, 1999).” As an IMVP researcher who later became an automotive industry analyst at an investment

going to holders of common and Class B stock (the latter held by members of the Ford family). Financial difficulties at Visteon led to Ford reacquiring 23 plants and offices in 2005; subsequently 30 plants or units were closed or divested. By 2010, Ford's share of Visteon's business was down to 28\%, with Hyundai in second place at $27 \%$. The Delphi and Visteon stories are similar in that both GM and Ford had concluded by the mid1990s that the advantages of vertical integration (reduced transaction costs, capture of supplier margin) were less than its costs (lack of exposure of parts units to external competition; high labor costs at both assembly and component plants). 
bank, Max Warburton, wrote at the time, "Modularity is an easy and digestible concept for consultant and investment banking firms to pick up on and use as a focus for their advisory activities - which is having a significant influence on firm strategies, particularly with respect to M\&A activity (Sako and Warburton, 1999)."

The influence of these ideas on OEMs' senior management was clear. A corporate strategist at Fiat shared a 1998 consultant's report that predicted industry-wide adoption of modularity by 2010 , driven by cost savings: "The recognition of the cost savings potential through the use of assembly modules is becoming stronger within the OEMs. There remains some resistance, but it is misguided and will be overcome in a relatively short time (Berkt Group, 1998). " In the U.S., IMVP researcher Daniel Whitney observed the ubiquity of two books, Clayton Christensen's The Innovator's Dilemma and Carliss Baldwin and Kim Clark's Design Rules, on the shelves of product engineers during a 2000 visit at one of the Big Three OEMs. In a personal communication, he wrote:

Certain words were obligatory and one of these was modularity. Modularity, to many people, meant outsourcing, which in turn meant job loss; while to others it meant devolving design responsibility to 'full service suppliers.' I was told that the Christensen and Baldwin \& Clark books had been declared required reading. [My internal contact at the OEM] felt that it over-simplified a complex situation and forced people to agree with top management's decisions instead of working through the problem themselves.

Carliss Baldwin (personal communication) added:

In the late 1990s, Kim [Clark] as well as Clay [Christensen] were in an evangelizing mode and the frameworks were just out. Kim in particular had a longstanding relationship with the Ford CEO, and I know they discussed our work. At the time, we were more concerned with the risk of power devolving on suppliers (the Intel story) than with the possibility that the framework just didn't fit.

This helped shape the views promulgated by the CEO office of Ford.

Suppliers quickly recognized their opportunity. If they could gain control of key

modules, from design to production, they could command higher prices. The resulting higher margins could drive greater investment in $\mathrm{R} \& \mathrm{D}$, better managerial and engineering capabilities, and better financial performance. Overall, suppliers' initial response was to 
accept the new strategic vision and prepare for their new roles. Tables 1a and A4 provide quotes from OEM, supplier, and third-party respondents pertaining to this shared prospective strategic vision for $\mathrm{M}+\mathrm{O}$. At this early stage, the degree of consensus is striking.

Meanwhile, OEMs seemed quite oblivious to the strategic risk. In addition, the key decision makers were not as concerned as one might expect with the substantial contractual hazards these new arrangements would incur. Had they paid closer attention to everything third-party actors said, they would have soon found cause to worry. ${ }^{16}$

\section{Framing Contests and Signs of Trouble}

To understand the evolution of these initiatives, we must dig into the intra-organizational debates within OEMs, and also the dialogue between OEMs and Tier 1s. As noted, megasuppliers welcomed their new role, but how exactly did they negotiate the early steps towards this major structural change? In the face of huge enthusiasm from senior management, how did different functional groups within the OEM view the advantages and disadvantages? Why was there consensus, albeit temporary, to align OEMs and Tier $1 \mathrm{~s}$ behind this new direction?

From the start, suppliers anticipated that building a module would be regarded as a high-value-added task, allowing them to charge more. But they quickly learned that OEMs did not see higher value-add in routine assembly tasks, so they pressed OEMs to go one step further and outsource design tasks to them. This aligned well with the strategic inclinations of OEM senior managers.

For suppliers, a bigger role in design innovation and integration of modules was appealing in several ways. Long constrained by OEMs' hierarchical supply chains, they saw $\mathrm{M}+\mathrm{O}$ as their chance to break free. Given more autonomy, they might also develop industry-

\footnotetext{
${ }^{16}$ According to a report on modularity based on data from this time period (Ro, Liker, and Fixson, 2007), "It is clear that OEMs are putting themselves at great risk when they outsource so much of the intellectual property in the vehicle. When a vehicle is a bolted-together set of modules, the quality and even appeal of the vehicle will depend at least as much on the module suppliers as on the OEM... Thus, OEMs are investing a great deal in specific assets ... when they engage a supplier to engineer and build modules."
} 
level standard components that could provide high-volume sales, tremendous economies of scale, and more influence on vehicle performance.

However, functional groups within OEMs had concerns about granting suppliers that expanded role. Individual managers and engineers differed in their opinions on the potential of modularity, so framing contests took place both across and within functional groups.

Tables $1 \mathrm{~b}$ and A5 contain data from our fieldwork on changing perspectives within OEMs.

Insert Tables $1 \mathrm{a}, 1 \mathrm{~b}, 1 \mathrm{c}$ about here.

Purchasing worried about controlling more powerful suppliers, and about the risks of hold-up and renegotiation that TCE would have brought up. The changes under way seemed to be introducing significant new risks. Product engineering doubted whether suppliers' design capabilities were up to scratch, and often did 'shadow engineering' of their efforts. Manufacturing questioned whether suppliers were as efficient at building subassemblies as OEM plants could be, and also faced labor union backlash over job losses from outsourcing. Overall, the fear was that outsourcing modules meant losing control.

Those with reservations were initially brought on board in two ways. First, they acknowledged the strategic imperative to reduce costs, improve ROA, and speed up innovation, and reluctantly accepted that modularity could help achieve these goals. Second, they were persuaded that modularity would be approached step by step, gradually extending suppliers' responsibility and autonomy as they proved worthy.

Despite these good intentions, $\mathrm{M}+\mathrm{O}$ soon ran into trouble. Our fieldwork revealed steadily growing concerns, on both sides, over whether the promised strategic benefits were materializing. OEMs cited inadequate supplier capabilities as a pretext for maintaining control, despite their avowed intent to transfer responsibility. Suppliers complained that OEMs wouldn't listen to their ideas, allow them to take charge, or let them earn sufficient margins to invest in improved capabilities, as the quotes in Tables 1c and A6 illustrate. 


\section{Realigned Expectations and Strategic Rethink}

As implementation faltered, misgivings turned to skepticism. This prompted a realignment of expectations and a rethinking of strategy. Now frictions (and framing struggles) were between Tier 1 managers wanting to hold OEMs to the initial vision and now-ascendant skeptics at OEMs.

Tables 2a / A7 show that OEMs chose to maintain hierarchical control over the supply chain, for multiple reasons. Where supplier capabilities were lacking, Ford purchasers worried about being 'held hostage' by a module supplier's inferior quality, as TCE would have predicted. Conversely, Fiat product engineers worried that where 'super suppliers' had developed innovative components for competitors, they would not necessarily share those new technologies. These examples of supplier opportunism hadn't been fully anticipated or negotiated at the outset. Other quotes show why OEMs chose to retain their system-integrator role: to control suppliers that weren't ready to take full responsibility, and to meet their own regulatory and liability requirements. The final two quotes suggest that OEMs were beginning to recognize the folly of relinquishing the system-integrator role to suppliers.

Tables $2 \mathrm{a} / \mathrm{A} 8$ present the complementary supplier perspective, which changed after suppliers: 1) saw how hard it would be to amass the necessary capabilities; 2) discovered that OEMs intended to maintain hierarchical control; 3) recognized the undesirability (if not impossibility) of taking on regulatory certification; and 4) saw that OEMs consistently vetoed the idea of standardized components across customers. As the new vision of $\mathrm{M}+\mathrm{O}$ was de facto toned down by the OEMs, suppliers did not merely complain, but tried to argue that OEMs were going to lose out on the hoped-for benefits by refusing to relinquish control. It not only reflected suppliers' interest, but also the buy-in and preparation of suppliers for the new roles laid out by the initial strategic vision upon which both parties had agreed. 
By showing the evolution of views in the sector, this evidence helps us understand the nature of the feedback loop posited in Figure 1: Efforts to change the sector were slow-paced, such that the final outcome of change efforts could not be known before the potential mistake materialized. It's not that signs of trouble were absent, or didn't amass; but rather that it took time for actors to process them. Changing course would mean admitting a mistake, and possibly trying to remedy it. Unsurprisingly, this created significant resistance and delay.

Insert Tables $2 \mathrm{a}$ and $2 \mathrm{~b}$ about here.

\section{Sector Architecture: What Changed, What Didn't, and Why Value Stuck Around}

If suppliers had hoped to gain an advantage through modularity, their hopes were soon dashed. Once they took off their strategic blinkers, OEMs managed to nip value migration in the bud and retain the dominant share of industry value. ${ }^{17}$ They could rescue the situation thanks to the slow pace of change in their industry, skepticism among their own functional groups, and a gradual rethink of faulty strategic premises.

Modularity initiatives, launched with such optimism and grand vision in the late 1990s, were mostly closed down, abandoned, or redirected within five to seven years, as summarized in Figure 3. Fiat dropped its modularity strategy by 2001, and by 2005 was reintegrating the design of core products back into its own central engineering group (Zirpoli and Whitford, 2014). Ford quietly disbanded its Modularity Task Force in 2003. ${ }^{18}$ Chrysler, which became part of DaimlerChrysler in 1998, continued with a few supplier-produced

\footnotetext{
${ }^{17}$ Data on the share of sectoral value captured by OEMs vs. suppliers between 1984 and 2004 (Jacobides and MacDuffie, 2013) found that the OEM share was both large (70-80+\%) and relatively stable despite the deverticalization in that period, in contrast with the pattern for the computer sector in the same years, where value shifted dramatically from OEMs to specialized suppliers.

${ }^{18}$ For Ford, which had invested heavily in making a shift to 'becoming a consumer services company,' the failure to gain much advantage from modularity, combined with the recession of the early 2000s, prompted a rethink of the entire strategic vision. While the CEO had initially promoted M+O in the late 1990s, he was too distracted by other difficulties in the early $2000 \mathrm{~s}$ - including the failure of the 'consumer services company' strategy - to give the modularity initiative much attention. Ford was able to reverse course because the progress of its initiative was slow, its momentum was stalled, and there was no unified coalition within the firm to support it. The initial consensus between Ford and its suppliers, which internally took the form of a truce across the different functional groups, didn't hold as problems emerged, and in the absence of strong leadership, the doubters carried the day. Of course, it was fortunate for Ford that it couldn't go too far down that risky road.
} 
modules, but abandoned co-design with suppliers and, in 2007, was bought by Cerberus.

Other OEMs encountered their own idiosyncratic barriers to progress towards modularity. ${ }^{19}$

Insert Figure 3 about here.

Yet it would be wrong to infer that entrenched interests and ineffective change agents meant

'business as usual.' Recall that there were dramatic structural changes in the form of reduced vertical integration at OEMs and the emergence of Tier 1 'mega-suppliers' of unprecedented horizontal scope, revenues, and growth rate. Given a history of OEMs dominating suppliers, the experimentation with collaborative design did alter the balance of power by giving suppliers a stronger hand in their age-old mixed-motive relationship with OEMs. Ultimately, though, OEMs kept hierarchical control over suppliers by retaining and also reprioritizing their central role as system integrators. At first, $\mathrm{M}+\mathrm{O}$ was a powerful double-pronged vision for restructuring the sector, but later the two themes were decoupled. Outsourcing continues to this day, while modularity largely stalled.

What aspects of the status quo ante industry structure affected pressures for change such that OEMs' role as system integrator was ultimately reinforced? With the benefit of hindsight, it is clear that OEMs had a safety net of sorts in the key structural characteristics of the automotive sector. First, unlike the computer sector, which unbundled into independent vertical segments that could be 'mixed and matched,' the automobile sector was clearly

\footnotetext{
${ }^{19} \mathrm{GM}$ was on a similar path to Ford in 1999 , but ceased to pursue modularity of production due to conflicts with the UAW. A Japanese firm like Toyota already worked closely with suppliers in its keiretsu on collaborative design and so was gaining the benefit of supplier expertise even without relinquishing control to them or shifting product architecture towards modules. VW drew analyst attention with its projection of massive economies of scale by extending a few core modules across multiple products sharing a platform in its family of brands, yet the primary gain arose from restricting the parameters given to design engineers; all modules were still proprietary (closed) designs and they differed in manufacturing specification across, for example, Skoda, SEAT, VW, and Audi. Perhaps the OEM that made the most progress towards modularity was Hyundai, in collaboration with Tier 1 supplier Mobis, which like Delphi and Visteon was a spinoff of formerly vertically integrated parts divisions. As noted in Figure 3, Hyundai was able to advance modularization processes through a quasi-vertically integrated relationship with its primary module supplier. Note that this was the opposite of the initial strategic vision advocated by the U.S. OEMs and the third party actors, which envisioned the handoff of responsibilities from the OEM to an autonomous supplier that would provide value through its specialized expertise, the focus on its core competence, quicker innovation, and reduced coordination costs.
} 
hierarchical. Thus, vertical dis-integration was achieved through extensive outsourcing that preserved hierarchical control of the supply chain.

Second, OEMs have responsibility for regulatory compliance, are accountable for product defects/failures (i.e. legal liability), and maintain the locus of differentiability by owning brand distinctiveness and controlling aftermarket parts. To fulfill these roles, they need to maintain their capabilities as system integrators - which $\mathrm{M}+\mathrm{O}$ threatened to undermine. The more OEMs denied supplier proposals for standardized parts or supplierbranded components, the more they seemed to realize the risks of value migration contained in their earlier strategic vision. Along with their misgivings over suppliers' capabilities, claims, and requests, this rightly gave the OEMs pause for thought.

Finally, OEMs have near-exclusive control over distribution through the franchised dealer model. This gives OEMs the ability to monopolize consumer interactions with valuable information to customize their offerings that suppliers lacked. Moreover, the clockspeed of the automotive industry was slow enough, with four- to six-year product cycles and incremental change in component technologies, to allow second thoughts.

Quotes from our field work that capture these channeling effects are summarized in Tables 2a, 2b, A7, A8, and A9, and the theory is illustrated in Figure 4.

Insert Figure 4 about here.

In summary, OEMs' strategic choices evolved via experimentation and sense-making as they balanced pressures from different internal constituencies. Their experience with modularity, and ill-fated moves into downstream services, made OEMs acutely aware that creating a new sector architecture through 'hollowing out,' shifting downstream, and modularizing was nowhere near as effective as external advisors and consultants had 
promised. ${ }^{20}$ OEMs' change of strategy in the early 2000s suggested they finally realized that their core competence was system integration: designing complete vehicles, complex subassemblies, and proprietary components to achieve a differentiated 'look and feel.'

\section{Impact on Value Distribution}

The same factors that underpinned OEMs' ability to control their IA also drove their ability to appropriate value. Despite significant outsourcing, OEMs retained hierarchical control of the supply chain through proprietary (closed) design specifications that not only required asset-specific investments by suppliers, but also avoided wholesale 'vertical unbundling' by ensuring that supply networks were hierarchically managed, without standard interfaces in production or distribution ${ }^{21}$ and using competitive bidding to preserve sourcing alternatives. OEMs found it easier to control an external supplier than an internal parts division. As a manufacturing engineer at Fiat put it, "We can be tougher and more rigid with a supplier, on cost and quality, than if we do it ourselves." Competitive bidding among suppliers give OEMs more scope to press for cost reductions than the transfer pricing associated with vertically integrated component production.

However, the fact that the IA remained hierarchical, preventing value migration, was not just a matter of strategic design. In the quest to simplify their product development and manufacturing, OEMs often resorted to more parts-sharing across platforms and models, especially for components that customers didn’t see. Occasionally, to meet this goal, OEMs would consent to purchasing a component that was also purchased by many other customers, which conflicted with the goal of keeping control over specifications.

Such de facto industry standards raised the potential for suppliers to feel the heat from defects and product recalls. Even without direct regulatory accountability or legal liability,

\footnotetext{
${ }^{20}$ For example, Ford's strategy to prioritize downstream consumer services didn't last much longer than its modularity initiative (Mercer, 2009). As of 2004 (by which time CEO Nasser had been forced out), virtually all of the diversifying acquisitions into services (listed in footnote 12) had been ended, i.e. unwound or sold.

${ }^{21}$ The automobile sector uses a small number of 'industry standard' interfaces, e.g., how tires and spark plugs are fastened, how refueling is done, etc. OEMs also provide specifications allowing post-sale suppliers in spare parts to compete, while also engaging in after-sales support. However, the production and distribution of the car largely eschews standardized interfaces, opting for closed, proprietary ones that maintain hierarchical control, impede full modularization, and preserve OEM value — as we found.
} 
contract provisions would ensure that suppliers felt the cost impact. Furthermore, the more vehicles shared common parts, the wider the scope of a potential recall, and the greater the risk of a supplier gaining notoriety among consumers. Still, for a mega-supplier to have a large market share of a component that many OEMs buy is different from establishing and controlling an industry-standard for a vital module; this modest move towards outsourcingplus-parts-sharing hasn't altered the fundamental reality of OEM power over Tier 1s. ${ }^{22}$

Even with new technologies such as electric drive trains and autonomous vehicles, which could change the dominant design of the automobile for the first time since the 1920s, OEMs must still integrate new and old technologies within a given vehicle design, and manage a portfolio of vehicles with a mix of such technologies. OEMs continue to do the lion's share of R\&D in their sector, even for new technologies like electric batteries, because they believe it is a competitive necessity that they 'know more than they make' (Brusoni, Prencipe, and Pavitt, 2001) in order to manage technically sophisticated mega-suppliers. At the same time, mega-suppliers, for all their increased capabilities and skills, are mostly shying away from the capital- and scale-intensive tasks of systems integration at the level of being a full assembler. ${ }^{23}$ Even new entrants (such as Tesla) have by and large preserved the patterns of the division of labor in the sector - and the dynamics of value appropriation. ${ }^{24}$ In

\footnotetext{
${ }^{22}$ A recent example shows how far the pendulum has swung from OEMs' brief enthusiasm for sourcing entire modules from Tier 1 suppliers. Seat maker Johnson Controls Inc. (JCI) has the largest market share worldwide yet has recently reported that it wants to sell its seating unit. The reason is that OEMs no longer want to purchase complete seats from JCI, preferring instead to make bulk purchases of individual components and then to hire a different supplier to do final assembly. This reduces the seat price for OEMs but leaves seat suppliers with much lower margins. In 2005, OEMs bought $70 \%$ of their seats as a single module from one suppliers, with 30\% assembled from components. Now those percentages are reversed (Sedgwick, 2015). JCI's capabilities for designing complete seats are utilized much less. Presumably the system integrator role that JCI once played for seats is now subsumed by OEMs retaining (and taking back) that role for themselves.

${ }^{23}$ Magna's brief flirtation with buying Opel marked the first instance of a supplier bidding to become an OEM since the industry's early history. That it failed in its attempt, due to GM's board changing its mind about the advisability of the sale, prevents us from finding out whether Magna would have been able to master the full set of capabilities required of global OEMs in the current era.

${ }^{24}$ Tesla's recent challenge of the franchise model is an effort to alter the nature of downstream relationships in the existing IA. On the upstream / production side, however, Tesla has broadly kept the attributes of existing OEMs supporting the current IA. It is also interesting to note that the dominant analogy in the sector has shifted from the focus on the computer sector to a fascination with Apple. Its ability to control its ecosystem through hierarchical arrangements and aggressive control of business and product design, despite the extensive use of outsourcing is widely admired (see Jacobides and MacDuffie, 2013).
} 
our view, these disruptive technological changes are unlikely to undermine the OEMs' system integrator role, or their share of value capture.

\section{DISCUSSION}

Our study looks at the process of industry transformation, focusing on changes in how production is organized, and related rules and roles. We thereby complement the rich tradition on industry evolution (see Audretsch, 1995; Geroski, 2005; Klepper, 1997; Nelson and Winter, 1982) by moving beyond the analysis of new processes and technologies to consider how industry architecture and scope change over time (Williamson, 1985). We also show that groups of firms, as well as individual firms, may undertake changes in their scope that are fraught with contractual hazards.

Our focus is on the endogenous mechanisms of change. We extend research on the evolution of institutional arrangements in a sector (Jacobides and Winter, 2005; Langlois and Robertson, 1995) by considering how actors try to change the rules that define the division of labor - and, consequently, the division of profit (Jacobides et al., 2006; Pisano and Teece, 2007). We thus complement Langlois and Robertson's (1989) analysis of early automotive sector history by arguing that there is more at play than changing economics or the availability of suppliers. Our study considers the role of strategic moves by major actors in the industry, looking within these actors to understand what drives and what constrains their actions, thus expanding our understanding of what drives the sector's templates (Jacobides and Winter, 2005). Our contribution is to explore the roles of both agency and structure.

We explore agency by looking at how different actors perceive their roles in the sector-wide division of labor, and try to rewrite them. We find that OEMs have been much more active than we might expect, proactively trying to alter their context via a transformative vision for themselves and the industry overall. We consider how dominant firms, responding to their own narrow pressures, pursue courses of action that might not even 
serve their best interests in the medium term, through a coalition of both intra- and interorganizational actors and agendas, as evidenced by OEMs' strategic U-turn.

As we consider agency in this way, we see a mix between the rational and the behavioral. While actors broadly follow their interests, there is a great deal of variance in the skills they bring to bear, the visions they develop, and the framing and cognitive strategies they use to advance them. Our analysis thus contributes to the growing literature on cognition (Porac et al., 1989, 2011), frames, and rhetorical contests (Kaplan, 2008; Kaplan and Tripsas, 2008). Our focus is at the level of the sector, and how industry architectures emerge both as a result of a truce between the different participants and also the cognitive perception of a template for understanding organization and the division of labor.

Our findings support the assertion that "executives adopt a way of looking at situations that are widely shared within their industry," i.e. industry recipes (Spender, 1989: 188). However, we also look at how different actors and segments interact, and how and why they try to change the ways in which they interact. Within these framing contests, we note the role of analogies (at times poorly chosen), influenced by the agendas of participants, advisors, and financiers. In particular, through the process model in Figure 1, we show how these forces help shape the patterns of division of labor and thus division of profit.

Second, our study contributes to the understanding of the role of structure in IA evolution. OEMs were powerful enough to launch strategic restructuring of the entire sector; their vision was ill founded strategically; and hence the initiatives would have weakened them, if completed. Yet, because of the hierarchical structure of the sector and their ensconced role as a systems integrator, the OEMs retained enough power to prevent slippage towards strategic weakness by partially halting the initiatives, unlike their counterparts in the computer sector. This underscores two important structural attributes: 
1) Sector-level vertical dis-integration, based on hierarchical non-modular structures and proprietary (closed) standards, as seen in autos, is different from wholesale vertical unbundling through modularity and open standards, as seen in computers (Baldwin and Clark, 2000). By backing away from unbundling and opting for deverticalization, automobile manufacturers could discipline and redirect their suppliers and keep a substantial part of the value-add, even while outsourcing massively. This is consistent with Luo et al. (2012), who find major differences in the hierarchical structures of production in automobiles and electronics in Japan. We thus inform the literature on global value chains (e.g., Sturgeon, 2002; Gereffi et al., 2005) and on the drivers of value creation and capture as they relate to vertical scope (Helfat and Campo-Rembado, 2014).

2) We also look at the role of regulatory responsibility and legal liability as a reinforcing mechanism of the status quo, which represents an under-studied and under-theorized element in terms of the relationship between different players in a sector (see, e.g., Kolstad, Ulen, and Johnson, 1990; Shavell, 2007). We also point to the role of ownership of the customer experience and/or distribution as a crucial attribute of sector structure that helps to explain both patterns of value distribution and the likelihood of change.

Our analysis of sector-wide phenomena also contributes to the growing debate on the process of change in institutional fields (Ferraro and Gurses, 2009; Lounsbury, 2007) by exploring the agency and identity of those trying to promote change. Firms such as Fiat and Chrysler, weakened by the 'hollowing out' from previous layoffs, were more resource-needy than other OEMs at the time, and this may have emboldened them to embark on vertical unbundling. Thus, consistent with Sine and David (2003), we find that resource scarcity does promote the reconsideration of a sector's institutional templates. Yet Ford and Hyundai both proactively embarked on modularity initiatives from a position of strength. Here, the impetus for change is not an exogenous shock, but rather an initiative from key powerful actors. 
Our study unpacks firms' advocacy for institutional change as the composite of internal dynamics, whereby groups within powerful actors can push for actions that jeopardize those actors' control of their environment. This provides an interesting link to the BTOF (Cyert and March, 1963) - i.e., to understand field-level changes, we need to consider the biases, interests, and coalitions arising from agency within firms.

Our analysis provides a set of mediating variables not directly considered in the literature on industry evolution. ${ }^{25}$ Also, by focusing on framing contests within and between buyers and suppliers, we confront the dilemmas associated with the co-determination of value creation and value capture.

Our final substantive contribution is a multi-level analysis of industry-level change. We argue that to understand change or stasis, we have to understand the agency of different groupings within firms, with their own distinct frames, interests, and biases. This analysis is consistent with Whitford and Zirpoli's (2015) recent account of the dynamics within Fiat. It draws on the BTOF (Argote and Greve, 2007; Cyert and March, 1963) to consider how differences within organizations drive firm-level decisions, and expands that theoretical tradition to show how these differences also shape sector-level outcomes.

This contribution also contextualizes TCE research (Williamson, 1985), while responding to Coase's (2006) exhortation to explore what drives scope without a priori bias. ${ }^{26}$ Consistent with TCE, we find that purchasing managers and engineers identified the contractual hazards, and tried to protect their firms. However, extending TCE, we find that

\footnotetext{
${ }^{25}$ Our study partly confirms and partly qualifies recent work on emerging industries. As Ozcan and Santos (2014) find for mobile payments, we also argue that incumbent support is critical to enable industry change. Yet we find incumbents in autos both less 'strategic,' and, at times, more prone to strategic mistakes as they consider the future form of their sector, despite its slower technological clockspeed. We also agree with Gurses and Ozcan's (2014) finding that different players try to engage in sector-wide framing contests. But in our case, the contests are not with regulators, nor do they involve public discourse.

${ }^{26}$ Coase (2006) challenges the established wisdom on the canonical example of TCE, suggesting that the Fisher Body acquisition of GM in 1926 (Klein, Crawford, and Alchian, 1978) was a foible. He argues that "as [the] theory was not based on the result of investigations into how firms did in fact act, it is not surprising that, as we have seen, the conclusion reached was completely wrong. What is needed is a change in the way economics is conducted. If our discussions are to have any value, our theories must have an empirical basis" (2006: 226-7).
} 
within-firm struggles resulted in contractually risky approaches winning the day. Our findings are also consistent with TCE in suggesting that firms that engage in transactional mis-alignment (such as excessive dis-integration) ultimately try to 'row back,' and qualify TCE by suggesting that this is possible only when some structural features allow it.

Finally, this research is informed by, and further qualifies, the considerable work on the evolution of the automotive sector (see, inter alia, Helper, 1991; Langlois and Robertson, 1989; Womack et al., 1990). First, we draw on the extensive body of research, and use it to triangulate our approach. Second, we help revisit the trends in the sector, in particular the push by firms towards the combined strategy of modularization and outsourcing during the late 1990s (MacDuffie, 2013). Third, we place our findings in the context of broader changes in the sector, such as the competition between the U.S., Japanese, and European firms, to ensure we have not spuriously captured other factors. And fourth, we provide a new angle on the nature of joint value creation in the context of buyer-supplier relationships.

\section{Limitations}

Our paper examines a single industry that may not be representative with respect to the potential impact of combining modularity and outsourcing strategies. Indeed, if the computer sector lies at one extreme, with a modular product architecture embedded in a modular industry structure, the automotive sector lies relatively close to the other, i.e. largely integral product architecture embedded in a largely hierarchical industry structure. While examining extreme cases can be analytically useful, it leaves the more representative intermediate cases unexplored. Also, the agreed-upon definitions-in-use of modularity in the automotive sector stand at some distance from both the academic literature and usage in other sectors, as explained in MacDuffie (2013). This requires us to look past the terminology to the underlying phenomenon: to identify the high degree of design interdependencies affecting what the automotive industry defines as 'modules,' and interpret the subsequent inter- 
organizational arrangements with respect to product, organizational, and industry architecture. Because an automobile is a complex multi-technology product with a complex multi-layered industry structure, we cannot apply a simple dichotomous characterization of modular vs. integral to either product or industry architecture. What can be said definitively is that the introduction of 'modules,' as interpreted in this setting, did not yield its anticipated benefits, and that the strategic and contractual hazards soon came to the fore.

As for methods, the bulk of the data were collected between 1998 and 2003. While it is an advantage to have data collected contemporaneously with the strategic initiatives we analyze, complemented as it was with our more recent interviews, we made no effort to gather the same sort of comprehensive data in this recent time period. Also, while the IMVP research team did collect data from a large number of OEMs and suppliers, the second author was not present for all of the company visits. While we had some access to the field notes of other researchers, we primarily focus here on the interview notes taken by the second author. This means the data from OEMs and suppliers is not precisely matched.

\section{CONCLUSION}

We explored how agents, and in particular firms that dominate their IA, proactively seek to change their sector's architecture. We find that dominant firms actively seek to reshape rules and roles when circumstances prompt them to reframe their own interests. They do so by engaging in both intra- and inter-organizational framing contests so as to legitimize and implement their chosen strategic initiatives. Through trial and error, they learn that certain initiatives are ineffective, or even harmful, and abandon them.

One of the key factors that dictate whether or not dominant firms can change their sector - and subsequently do change their minds - is its structural characteristics. We find that the nature of hierarchical arrangements in the existing IA; certification and legal accountability; the link with final customers; and access to distribution all affect the ability of 
OEMs to control the evolution of their sector and appropriate value. We also see that to understand the agency of leading firms, we need to look at the dominant groups within organizations, whose agendas, interests, and biases shape organizational responses.

Overall, we show how sector-level changes are sought by dominant firms, how the existing structure influences this initiative, and what drives the eventual outcome, be it stability or change. At a time of rapidly shifting ecosystems and IAs, with boundaries of sectors being redefined and large corporate moves changing the landscape in many sectors, we hope that our findings will not only be theoretically relevant but also practically useful. 


\section{ACKNOWLEDGEMENTS}

We first want to recognize the researchers involved in the original Modularity and Outsourcing Project that generated the data analyzed here, many of whom have provided valuable input on this and earlier versions of the paper: Sebastian Fixson, Takahiro Fujimoto, Susan Helper, Fiona E. Murray, Kentaro Nobeoka, Frits K. Pil, Mari Sako, Koichi Shimokawa, Akira Takeishi, and Max Warburton. Next we would like to acknowledge the feedback and advice of other friends and colleagues during the long process of guiding this paper to publication, including Ron Adner, Christine Ahmadjian, Charles Baden-Fuller, Carliss Baldwin, Markus Becker, Julian Birkinshaw, Arnaldo Camuffo, Saikat Chaudhuri, Michael Cusumano, Rich D’Aveni, Jason Dedrick, JP Eggers, Alfonso Gambarella, Annabelle Gawer, Connie Helfat, Vit Henisz, Dan Levinthal, Marvin Lieberman, Jianxi Luo, Glenn Mercer, Peter Murmann, Phanish Puranam, Dan Raff, Melissa Schilling, Nikolaj Siggelkow, Kannan Srikanth, Gus Stuart, Tim Sturgeon, Fernando Suarez, Jim Utterback, Freek Vermeulen, Daniel Whitney, Sid Winter, Francesco Zirpoli, and John Zysman. We also thank anonymous reviewers plus seminar participants in Wharton, NYU-Stern, Dartmouth, Bocconi, Singapore Management University and participants in the SMS Prague meetings, the ISA Pittsburgh meetings, and the AoM Boston meetings for comments and suggestions. Tom Albrighton has valiantly helped shorten and tighten the paper. The International Motor Vehicle Program has provided us with the opportunity to engage in sustained interaction with industry executives, as well as the financial resources to carry out much of this research. We are also extremely grateful to the many executives, managers, engineers, government officials, and industry analysts who, despite schedule pressures, have generously offered their time, thoughts and suggestions. Of course, we are solely and collectively responsible for any remaining shortcomings. 


\section{REFERENCES}

Adner R. 2012. The Wide Lens: A New Strategy for Innovation. Penguin: London, UK.

Argote L, Greve HR. 2007. A behavioral theory of the firm-40 years and counting: Introduction and impact. Organization Science 18(3): 337-349.

Argyres N, Bigelow L. 2010. Innovation, modularity, and vertical deintegration: Evidence from the early U.S. auto industry. Organization Science 21(4): 842-853.

Argyres N, Liebeskind J. 1999. Contractual commitments, bargaining power and governance inseparability: Incorporating history into transaction cost theory. Academy of Management Review 24(1): 49-63.

Asanuma B, Kikutani T. 1992. Risk absorption in Japanese subcontracting: A microeconometric study of the automobile industry. Journal of the Japanese and International Economies 6(1): 1-29.

Audretsh DB. 1995. Innovation and Industry Evolution. MIT Press: Cambridge, MA.

Baldwin CY. 2015. Bottlenecks, modules, and dynamic architectural capabilities. In The Handbook of Dynamic Capabilities, Teece DJ (ed). Oxford University Press: New York. Forthcoming.

Baldwin CY, Clark KB. 2000. Design Rules: The Power of Modularity. MIT Press: Cambridge, MA.

Benner MJ. 2010. Securities analysts and incumbent response to radical technological change: Evidence from digital photography and internet telephony. Organization Science 21(1): 42-62.

Benner MJ, Tripsas M. 2012. The influence of prior industry affiliation on framing in nascent industries: The evolution of digital cameras. Strategic Management Journal 33(3): 277302.

Berkt Group. 1998. The current status and trend of passenger car modularization in NAFTA and Europe. Consulting report.

Breschi S, Malerba F, Orsenigo L. 2000. Technological regimes and Schumpeterian patterns of innovation. The Economic Journal 110 (463):388-410.

Bresnahan T, Greenstein S. 1999. Technological competition and the structure of the computing industry. Journal of Industrial Economics 47(1): 1-40.

Brusoni S, Principe A, Pavitt K. 2001. Knowledge specialization, organizational coupling, and the boundaries of the firm. Administrative Science Quarterly 46(4): 597-621.

Christensen C. 1997. The Innovator's Dilemma. Harvard Business School Press: Boston, MA.

Coase R. 2006. The conduct of economics: The example of Fisher Body and General Motors. Journal of Economics and Management Strategy 15(2): 255-278.

Cusumano MA, Takeishi A. 1991. Supplier relations and management: A survey of Japanese, Japanese-transplant, and US auto plants. Strategic Management Journal 12(8): 563-588.

Cyert R, March JG. 1963. A Behavioral Theory of the Firm. Prentice-Hall: Englewood Cliffs, NJ.

Donovan D. 1999. The dawn of the mega supplier: Winning supplier strategies in an evolving auto industry. Bain \& Company Insights. Available at http://www.bain.com/publications/articles/Copy of Perform improv templates.aspx. Accessed on 28 September 2014.

Dosi G. 1982. Technological paradigms and technological trajectories: A suggested interpretation of the determinants and directions of technical change. Research Policy 11(3): 147-162.

Dyer J. 1996. Specialized supplier networks as a source of competitive advantage: Evidence from the auto industry. Strategic Management Journal 17(4): 271-291. 
Dyer J, Ouchi WG. 1993. Japanese style business partnerships: Giving companies a competitive edge. Sloan Management Review 35(1): 51-63.

Eggers JP, Kaplan S. 2013. Cognition and capabilities: A multi-level perspective. Academy of Management Annals 7(1): 295-340.

Ferraro F, Gurses K. 2009. Building architectural advantage in the US motion picture industry: Lew Wasserman and the Music Corporation of America. European Management Review 6(4): 233-249.

Fixson SK, Park JK. 2008. The power of integrality: Linkages between product architecture, innovation, and industry structure. Research Policy 37(8): 1296-1316.

Fligstein N. 2001. The Architecture of Markets: An Economic Sociology of Twenty First Century Capitalist Societies. Princeton University Press: Princeton, NJ.

Gavetti G. 2012. Toward a behavioral theory of strategy. Organization Science 23(1): 267285.

Gavetti G, Levinthal D. 2000. Looking forward and looking backward: Cognitive and experiential search. Administrative Science Quarterly 45(1): 113-137.

Gereffi G, Humphrey J, Sturgeon T. 2005. The governance of global value chains. Review of International Political Economy 12(1): 78-104.

Geroski PA. 2005. Understanding the implications of empirical work on corporate growth rates. Managerial and Decision Economics 26(2): 129-138.

Guba EG, Lincoln YS. 1982. Epistemological and methodological bases of naturalistic inquiry. Educational Communication and Technology Journal 30(4): 233-252.

Gurses K, Ozcan P. 2014. Entrepreneurship in regulated markets: Framing contests and collective action to introduce Pay TV in the US. Academy of Management Journal. Forthcoming.

Hannan MT, Freeman J. 1984. Structural inertia and organizational change. American Sociological Review 49(2): 149-164.

Helfat CE, Campo-Rembado M. 2014. Integrative capabilities, vertical integration, and innovation over successive technology lifecycles. Working paper: Dartmouth College.

Helper S. 1991. Strategy and irreversibility in supplier relations: The case of the US automobile industry. Business History Review 65(4): 781-824.

Helper S, Sako M. 1992. Supplier relations in Japan and the United States: Are they converging? Sloan Management Review 36(6): 77-84.

Henfridsson O, Yoo Y. 2013. The liminality of trajectory shifts in institutional entrepreneurship. Organization Science 25(3): 932-950.

Huber GP, Power DJ. 1985. Retrospective reports of strategic-level managers: Guidelines for increasing their accuracy. Strategic Management Journal 6(2): 171-180.

Iansiti M, Levien R. 2004. The Keystone Advantage: What the New Dynamics of Business Ecosystems Mean for Strategy, Innovation, and Sustainability. Harvard Business Press: Boston, MA.

Jacobides MG. 2005. Industry change through vertical disintegration: How and why markets emerged in mortgage banking. Academy of Management Journal 48(3): 465-498.

Jacobides MG, Knudsen T, Augier M. 2006. Benefiting from innovation: Value creation, value appropriation and the role of industry architectures. Research Policy 35(8): 12001221.

Jacobides MG, MacDuffie JP. 2013. How to drive value your way. Harvard Business Review 91(7-8): 92-102.

Jacobides MG, Tae CJ. 2015. Kingpins, bottlenecks, and value dynamics along a sector. Organization Science 26(3): 889-907. 
Jacobides MG, Winter SG. 2005. The co-evolution of capabilities and transaction costs: Explaining the institutional structure of production. Strategic Management Journal 26(5): 395-413.

Kaplan S. 2008. Framing contests: Strategy making under uncertainty. Organization Science 19(5): 729-752.

Kaplan S. 2011. Research in cognition and strategy: reflections on two decades of progress and a look to the future. Journal of Management Studies 48(3): 665-695.

Kaplan S, Tripsas M. 2008. Thinking about technology: Applying a cognitive lens to technical change. Research Policy 37(5): 790-805.

Kenney M, Florida R. 1993. Beyond Mass Production: The Japanese System and its Transfer to the US. Oxford University Press: New York.

Kerwin, K, Naughton K. 1999. Remaking Ford. Business Week, 10 October.

Kieser A. 1994. Why organization theory needs historical analyses - and how this should be performed. Organization Science 5(4): 608-620.

Klein B, Crawford RG, Alchian AA. 1978. Vertical integration, appropriable rents, and the competitive contracting process. Journal of Law and Economics 21(2): 297-326.

Klepper S. 1997. Industry life cycles. Industrial and Corporate Change 6(1): 145-182.

Klepper S, Simons KL. 2000. Dominance by birthright: Entry of prior radio producers and competitive ramifications in the US television receiver industry. Strategic Management Journal 21(10-11): 997-1016.

Kolstad CD, Ulen TS, Johnson GV. 1990. Ex post liability for harm vs. ex ante safety regulation: Substitutes or complements? American Economic Review 80(4): 888-901.

Langlois RN. 1992. Transaction-cost economics in real time. Industrial and Corporate Change 1(1): 99-127.

Langlois R, Robertson P. 1989. Explaining vertical integration: Lessons from the American automobile industry. Journal of Economic History 49(2): 361-375.

Langlois R, Robertson P. 1995. Firms, Markets, and Economic Change. Routledge: London, UK.

Leblebici H et al.. 1991. Institutional change and the transformation of interorganizational fields: An organizational history of the US radio broadcasting industry. Administrative Science Quarterly 36(3): 333-363.

Leonard-Barton D. 1990. A dual methodology for case studies: Synergistic use of a longitudinal single site with replicated multiple sites. Organization Science 1(3): 248-266.

Lounsbury M. 2007. A tale of two cities: Competing logics and practice variation in the professionalizing of mutual funds. Academy of Management Journal 50(2): 289-307.

Lounsbury M, Rao H. 2004. Sources of durability and change in market classifications: A study of the reconstitution of product categories in the American mutual fund industry, 1944-1985. Social Forces 82(3): 969-999.

Luo J, et al.. 2012. The architecture of transaction networks: A comparative analysis of hierarchy in two sectors. Industrial and Corporate Change 21(6): 1307-1335.

MacDuffie JP. 2013. Modularity-as-property, modularization-as-process, and 'modularity'as-frame: Lessons from product architecture initiatives in the global automotive industry. Global Strategy Journal 3(1): 8-40.

MacDuffie JP, Fujimoto T. 2010. Get ready for the complexity revolution: Why automakers will keep ruling the auto industry. Harvard Business Review (June): 23-27.

MacDuffie JP, Helper S. 2006. Collaboration in supply chain: With and without trust. In The Firm as a Collaborative Community: Reconstructing Trust in the Knowledge Economy, Heckscher C, Adler PS (eds). Oxford University Press: Oxford, UK; 417-466.

McGrath RG. 2001. Exploratory learning, innovative capacity, and managerial oversight. Academy of Management Journal 44(1): 118-131. 
McMillan JC. 1990. Managing suppliers: Incentive systems in the Japanese and US industry. California Management Review 4(32): 38-55.

Mercer G. 2009. The North American auto industry model: Is it time to look further downstream for value? Prepared for IMVP Executive Forum, Rochester, MI, June 9.

Miller D, Chen MJ. 1994. Sources and consequences of competitive inertia: A study of the US airline industry. Administrative Science Quarterly 39(1): 1-23.

Mohr LB. 1982. Explaining Organizational Behavior. Jossey-Bass: San Francisco, CA.

Monteverde K, Teece, DJ. 1982. Supplier switching costs and vertical integration in the automobile industry. Bell Journal of Economics 13(1): 206-213

Nelson RR, Winter SG. 1982. An Evolutionary Theory of Economic Change. Belknap: Cambridge, MA.

Ng D, Westgren R, Sonka S. 2009. Competitive blind spots in an institutional field. Strategic Management Journal 30(4): 349-369.

Nishiguchi T. 1994. Strategic Industrial Sourcing: The Japanese Advantage. Oxford University Press: Oxford, UK.

Nobeoka K, Manabe S. 2006. Jidousha buhin tokusei no sokutei (Measuring properties of automobile parts). Yokohama National University Working Paper (in Japanese).

Ozcan P, Santos FM. 2014. The market that never was: Turf wars and failed alliances in mobile payments. Strategic Management Journal. Forthcoming.

Pil FK, MacDuffie JP. 2000. What makes transplants thrive: Managing the transfer of "best practice" at Japanese auto plants in North America. Journal of World Business 34(4): 372-391.

Pisano G, Teece DJ. 2007 How to capture value from innovation: Shaping intellectual property and industry architecture. California Management Review 50(1): 278-296.

Porac JF, Thomas H, Baden-Fuller C. 1989. Competitive groups as cognitive communities: The case of Scottish knitwear manufacturers. Journal of Management Studies 26(4): 397-416.

Porac JF, Thomas H, Baden-Fuller C. 2011. Competitive groups as cognitive communities: the case of Scottish knitwear manufacturers revisited. Journal of Management Studies 48(3): 646-664.

Prahalad C, Hamel G. 1990. The core competence of the corporation. Harvard Business Review 68(3): 79-91.

Prencipe A, Davies A, Hobday M. (eds). 2005. The Business of Systems Integration. Oxford University Press: Oxford, UK.

Rao H. 2004. Institutional activism in the early American automobile industry. Journal of Business Venturing 19(3): 359-384.

Ro YK, Liker JK, Fixson SK. 2007. Modularity as a strategy for supply chain coordination: The case of US auto. IEEE Transactions on Engineering Management 54(1): 172-189.

Ross L. 1977. The intuitive psychologist and his shortcomings: Distortions in the attribution process. In Advances in Experimental Social Psychology, Berkowitz L (ed). The Academic Press: New York, NY; 173-220.

Rubenstein JM. 2001. Making and Selling Cars: Innovation and Change in the US Automotive Industry. Johns Hopkins University Press, Baltimore.

Sako M. 2009. Outsourcing of tasks and outsourcing of assets: Evidence from automotive supplier parks in Brazil. In Platforms, Markets and Innovation, Gawer A (ed). Edward Elgar Publishing: Cheltenham, UK; 251-344.

Sako M, Warburton M. 1999. Modularity and Outsourcing Project: Report of European Research Team. Prepared for the IMVP Annual Forum at MIT, October 6-7, 1999. Massachusetts Institute of Technology: Cambridge, MA. 
Santos F, Eisenhardt K. 2009. Constructing markets and shaping boundaries: Entrepreneurial power in nascent fields. Academy of Management Journal 52(4): 643-671.

Schumpeter JA. (1934). The Theory of Economic Development: An Inquiry into Profits, Capital, Credit, Interest, and the Business Cycle. Transaction Publishers: Piscataway, NJ.

Schumpeter J. 1950. Capitalism, Socialism, and Democracy. Harper \& Row: New York, NY.

Sedgwick D. 2015. Why seat king Johnson Controls wants out of the seat business. Automotive News, June 15.

Shavell S. 2007. Liability for accidents. Handbook of Law and Economics 27(1): 139-182.

Sine WD, David RJ. 2003. Environmental jolts, institutional change, and the creation of entrepreneurial opportunity in the US electric power industry. Research Policy 32(2): 185-207.

Skocpol T. (ed.) 1984. Vision and Method in Historical Sociology. Cambridge University Press: Cambridge, UK.

Song XM, Parry ME. 1997. A cross-national comparative study of new product development processes: Japan and the United States. Journal of Marketing 61(2): 1-18.

Spender JC. 1989. Industry Recipes. Basil Blackwell: Oxford, UK.

Sturgeon TJ. 2002. Modular production networks: A new American model of industrial organization. Industrial and Corporate Change 11(3): 451-496.

Takeishi A, Noro Y. 2005. Structural changes of Japanese supplier system. Presentation at IMVP Spring Researchers Meeting, Philadelphia, June 2-3.

Taylor CR, Wiggins SN. 1997. Competition or compensation: Supplier incentives under the American and Japanese subcontracting systems. American Economic Review 87(4): 598-618.

The Economist. 2008. Idea: Core competence. 15 September: Online supplement. Available at http://www.economist.com/node/12231124. Accessed on 28 September 2014.

Tripsas M. 1997. Unraveling the process of creative destruction: Complementary assets and incumbent survival in the typesetter industry. Strategic Management Journal 18(S1): 119-142.

Tushman ML, Anderson P. 1986. Technological discontinuities and organizational environments. Administrative Science Quarterly 31(3): 439-465.

Ulrich K. 1995. The role of product architecture in the manufacturing firm. Research Policy 24(3): 419-440.

van Wijk J et al.. 2013. Activists and incumbents structuring change: The interplay of agency, culture, and networks in field evolution. Academy of Management Journal 56(2): 358-386.

Walsh WB. 1967. Validity of self-report. Journal of Counseling Psychology 14(1): 18-23.

Whitford J, Zirpoli F. 2015. Pragmatism, practice, and the boundaries of organization. Organization Science. 25(6): 1823 - 1839.

Williamson OE. 1985. The Economic Institutions of Capitalism. Simon \& Schuster: New York.

Williamson OE. 1996. The Mechanisms of Governance. Oxford University Press: Oxford, UK.

Womack JP, Jones DT, Roos D. 1990. The Machine that Changed the World: The Story of Lean Production. Harper Perennial: New York.

Yin RK.1994. Case Study Research: Design and Methods. Sage: London, UK.

Zirger BJ, Maidique MA. 1990. A model of new product development: An empirical test. Management Science 36(7): 867-883.

Zirpoli F, Whitford J. 2014. The network firm as a political coalition. Manuscript under review. 


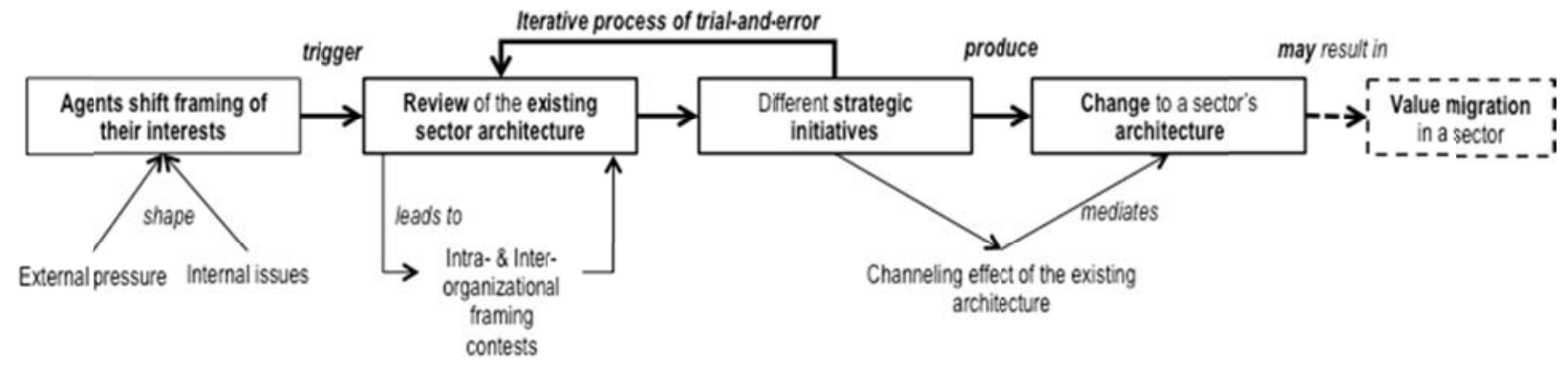

Figure 1. A process diagram of industry architecture change 

Increase in outsourcing and
modularization of components

Performance gap: Western vs Japanese OEMS

Japanese supplier mgmt. approach gaining attention

Suppliers seeking more

autonomy, value-add tasks

OEM issues w/ capabilities

(e.g. technical "hollowing-out"

at Fiat, Chrysler)

Production rethink - removal of subassemblies from OEM assembly plant, calling them "modules"
Emergence of ideology around modular / IT. like structure sponsored by OEMs with support of $3^{\text {rs }}$ parties (eg academics,

$$
\text { consultants) }
$$

Quiet abandonment of

Pressure on OEMs (C-level) to rethink

strategy, i.e. more focus, better ROA, new

business models

OEM attention shifts to modular design, w/

major role for suppliers

Framing battles within OEM: C- level \& purchasing support new vision whereas product engineering \& manufacturing

object, but relent

Spinoffs of Visteon (Ford)

and Delphi (GM), plus

mega supplier growth modular design structures

OEMs see problems with supplier

OEM regaining control,

keeping value add

quality, design capabilities, loss of

strategic control

Strategic initiatives transformed,

new frames emerge

Framing re-thought, as OEM

realize the risks

IA brought back to OEM contro

despite extensive outsourcing.

Suppliers face structural improved capabilities of mega-

boundaries, can't capture value and I suppliers

or prefer current role

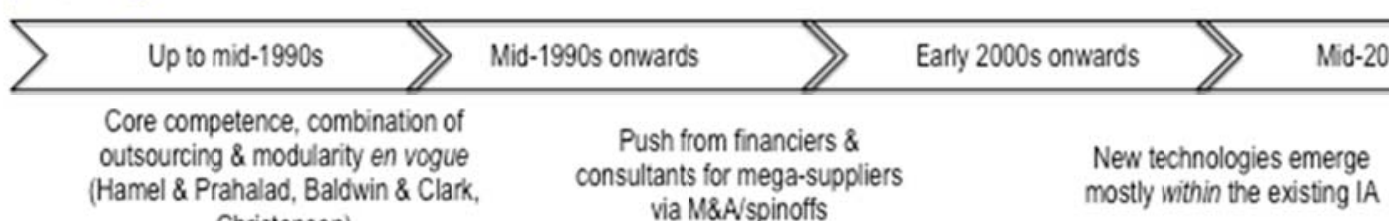
Christensen) 


\begin{tabular}{|c|c|c|c|c|}
\hline & $\begin{array}{l}\text { Coalition supporting M } \\
+0 \text { develops at OEMS } \\
\text { and suppliers }\end{array}$ & & $\begin{array}{l}\text { Pursuit of } \mathrm{M}+\mathrm{O} \\
\text { nitiatives; difficulties } \\
\text { with } \mathrm{M} \text { encountered }\end{array}$ & $\begin{array}{l}\text { Modification or } \\
\text { abandonment of } \mathrm{M} \text {; } \\
\text { persistence of } \mathrm{O}\end{array}$ \\
\hline Chrysler & $\begin{array}{l}\text { Hollowing out of engineering } \\
\text { capabilities during post-bankruptcy } \\
\text { period in } 1980 \text { s. M+O central in } \\
\text { strategic decision to collaborate w/ } \\
\text { suppliers, e.g. Extended Enterprise } \\
\& \text { SCORE (Supplier Cost } \\
\text { Reduction Effort) initiatives under } \\
\text { Purchasing VP Tom Stallkamp } \\
\text { starting in } 1990 \text {. }\end{array}$ & $\begin{array}{l}\text { Pressured by losses in the late } \\
80 \text { s and influenced by Japanese } \\
\text { collaborative approach with } \\
\text { suppliers, Chrysler is first US } \\
\text { OEM to outsource module design } \\
\text { as well as production to suppliers, } \\
\text { starting with cockpits (to X); } \\
\text { suspensions (to Y); }\end{array}$ & $\begin{array}{l}\text { Merged with Daimler Benz in } 1998 . \\
\text { New managers from DB } \\
\text { commission consultant study of } \\
\text { component costs and conclude that } \\
\text { Chrysler is overpaying suppliers. } \\
\text { Demand for immediate price cuts } \\
\text { marks end of SCORE and EE } \\
\text { initiatives. Stallkamp leaves in } \\
2000 \text {. DCX moves away from } \\
\text { collaboration w'suppliers. }\end{array}$ & $\begin{array}{l}\text { Design control of modules moves } \\
\text { back to DCX. Module initiative shifts } \\
\text { focus to supplier park planned for } \\
\text { Toledo, OH Jeep plant. From } 2006 \\
\text { on, } 3 \text { suppliers (Kuka, Magna, } \\
\text { Mobis) build large heavy modules } \\
\text { onsite in Toledo; focus is modularity- } \\
\text { for production plus lean supply } \\
\text { chain. }\end{array}$ \\
\hline Fiat & $\begin{array}{l}\text { Decision to move complex } \\
\text { subassemblies off the primary } \\
\text { production line in designing new } \\
\text { product (Tipo) and new automated } \\
\text { processes for Cassino (Italy). } \\
\text { implemented in } 1988 \text {. Subsequent } \\
\text { outsourcing of subassemblies to } \\
\text { suppliers in early } 1990 \text { s. }\end{array}$ & $\begin{array}{l}\text { After move to modular production, } \\
\text { mid-1990s strategic decision to } \\
\text { reorganize NPD, implement } \\
\text { modular product architecture and } \\
\text { involve suppliers in module } \\
\text { design. Based on belief of chief } \\
\text { strategists and bolstered by } \\
\text { commissioned consultant report } \\
\text { (1998) on the impending } \\
\text { dominance of modules. }\end{array}$ & $\begin{array}{l}\text { From } 1996-2001 \text {, drastic increase } \\
\text { in outsourcing of design } \\
\text { engineering to suppliers for } \\
\text { strategic flexibility, cost \& lead time } \\
\text { reduction, quality gains. Low capital } \\
\text { investment facilitates (and is } \\
\text { reinforced by) this move. Product } \\
\text { engineers increasingly worried } \\
\text { about "hollowing out" and being } \\
\text { held up by "super suppliers" } \\
\text { withholding innovative components. }\end{array}$ & $\begin{array}{l}\text { Modularity strategy dropped in } 2002 \text {, } \\
\text { due to lost competencies for module } \\
\text { design,system integration. Gradual } \\
\text { insourcing of design from } \\
2002-2005 \text {. New CTO hired in } \\
2005 \text {, begins re-establishing } \\
\text { competences, e.g. for cockpits. } \\
\text { Design for new 'template" vehicles } \\
\text { kept in-house, derivative model } \\
\text { design still outsourced. }\end{array}$ \\
\hline Ford & $\begin{array}{l}\text { Seats moved off main assembly } \\
\text { lines in U.S. and Europe starting in } \\
1980 \text { s. Supplier parks set up } \\
\text { around Ford's European ass'y } \\
\text { plants in early-to-mid } 1990 \text { s } \\
\text { facilitate production-oriented } \mathrm{M}+\mathrm{O} \text {. }\end{array}$ & $\begin{array}{l}\text { N.America strategy office ( } 8 \text { CEO) } \\
\text { push design-oriented } M+O \text { vision. } \\
\text { Modularity task-force set up in } \\
\text { 1999: } 19 \text { 'modules' identified. } \\
\text { Chief engineers urged to } \\
\text { incorporate modules during NPD. }\end{array}$ & $\begin{array}{l}\text { Visteon spun off in } 2000 \text {, begins } \\
\text { submitting module designs. At } \\
\text { Ford, internal debates over whether } \\
\text { modules bring desired benefits. } \\
\text { Few (or no) modules incorporated } \\
\text { during NPD, for varied reasons }\end{array}$ & $\begin{array}{l}\text { Modularity task force disbanded in } \\
2003 \text {. Broad push for modularity in } \\
\text { design dropped. Initial modules } \\
\text { outsourced for production (cockpit; } \\
\text { front end) maintained but Ford } \\
\text { retains design control. }\end{array}$ \\
\hline Hyundai & $\begin{array}{l}\text { After Korea financial crisis, } \\
\text { Hyundai acquires Kia+its suppliers } \\
\text { in 1998; begins to consolidate } \\
\text { subsidiaries; moves production } \\
\text { tasks from (union) assy plants to } \\
\text { (nonunion) supplier plants }\end{array}$ & $\begin{array}{l}\text { Hyundai Motor Company } \\
\text { separated from parent in } 2000 ; \\
\text { Mobis is new name of } \\
\text { consolidated parts firm. New } \\
\text { strategy to accelerate use of } \\
\text { modules for production gains } \\
\text { during global expansion. }\end{array}$ & $\begin{array}{l}\text { Hyundai/Kia \& Mobis engineers are } \\
\text { co-located at R\&D facility in Korea. } \\
\text { Extensive co-design efforts for } \\
\text { module improvements, esp.cockpit } \\
\text { electronics. Goal of selling to } \\
\text { modules to other OEMs. }\end{array}$ & $\begin{array}{l}\text { For Hyundai/Kia+Mobis, module- } \\
\text { level design innovations achieved } \\
\text { within production-defined module } \\
\text { boundaries. Difficulty in obtaining } \\
\text { outside contracts; success for } \\
\text { chassis module at Chrysler Toledo }\end{array}$ \\
\hline
\end{tabular}

Figure 3. The chronology of how strategic initiatives unfolded at select automotive OEMs 


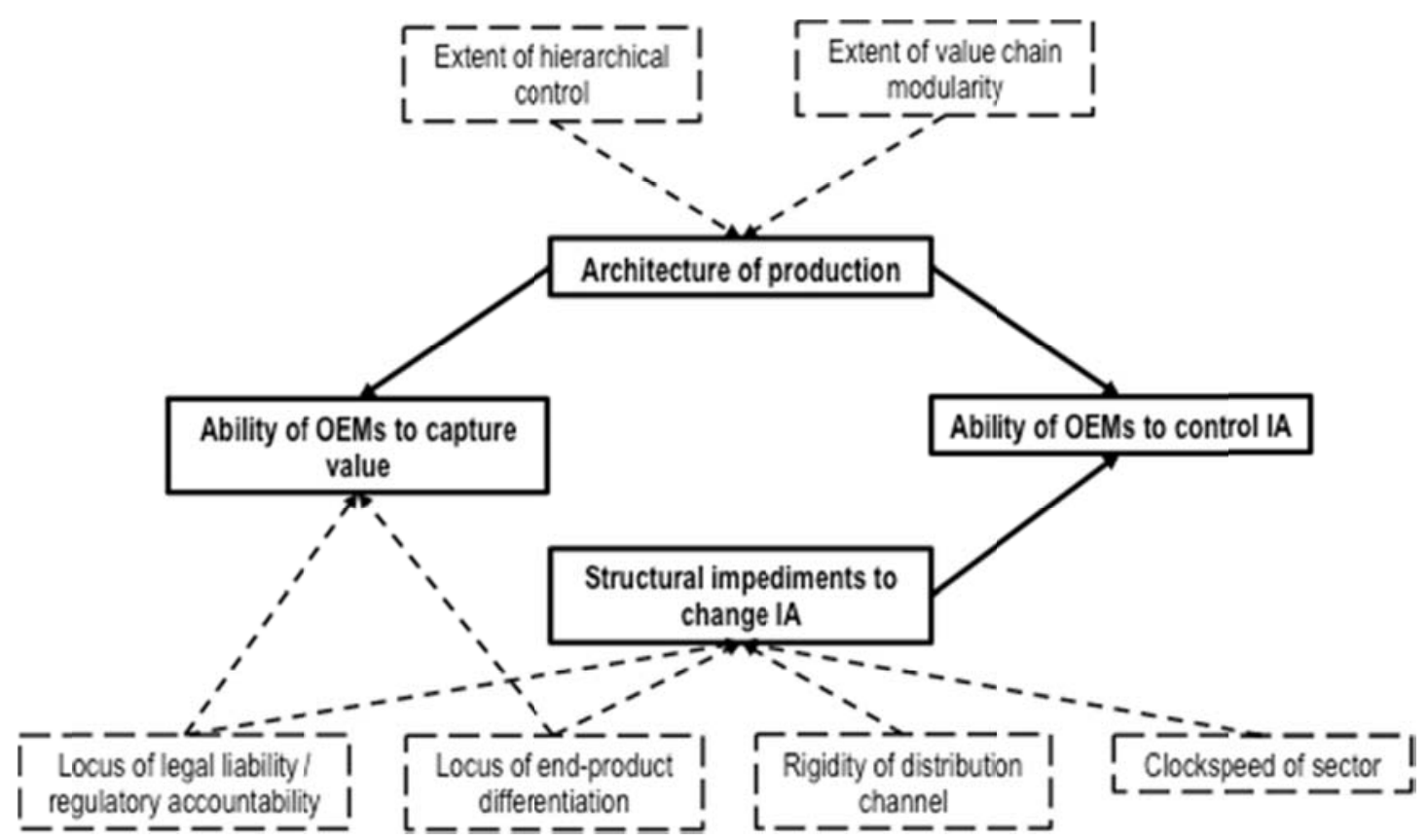

Figure 4. What drives the potential for leading firms' structural dominance 
Table 1a. Strategic vision for "Modularity + outsourcing"

\begin{tabular}{|c|l|}
\hline & $\begin{array}{l}\text { "Modules should get us to the next level- how to design } \\
\text { and build a vehicle quicker, better, cheaper, closer to what } \\
\text { customers want. If we do modules right, it will change how } \\
\text { we think about building the vehicle and it will put the } \\
\text { expertise where it should be, in the supply base.... We } \\
\text { Should focus on system engineering and standards." Ford, } \\
\text { corporate strategy. } \\
\text { - "The main strategy of Fiat is value creation. The goal of } \\
\text { module sourcing is to focus on our core competence.... We } \\
\text { started with internal modules. Now we want to focus on } \\
\text { core competence and to outsource the modules." Fiat, } \\
\text { purchasing. }\end{array}$ \\
\hline Supplier \\
advocates \\
$\begin{array}{l}\text { "Integration means the ability to remove chimney } \\
\text { organizations - where responsibiities are organized by } \\
\text { components - and replace them with a team that looks at } \\
\text { the module as one unit. Suppliers are better able to do this } \\
\text { because OEMs don't have the same depth of knowledge." } \\
\text { Supplier 1, product engineering. } \\
\text { "The opportunity for us is to get the chance to manage all of } \\
\text { this - to take charge of the customizing based on our } \\
\text { understanding of what each customer needs. "Supplier 2, } \\
\text { product engineering. }\end{array}$
\end{tabular}

Table 1b. Framing contests within OEMs: Debates over potential problems

\begin{tabular}{|c|c|}
\hline $\begin{array}{l}\text { Supplier } \\
\text { capabilities }\end{array}$ & $\begin{array}{l}\text { "We're now having the suppliers come in to tell us what } \\
\text { their capabilities are. We want to be able to certify that a } \\
\text { supplier is module-ready. They need lots of project } \\
\text { management skills. We expect them to manage the Tier } 2 \\
\text { and Tier } 3 \text { suppliers as well. They'll have to do all the } \\
\text { certification that we do, e.g. they'll have to be able to test for } \\
\text { wind noise the same way we would, meet all of our } \\
\text { requirements. "Ford, product engineering. }\end{array}$ \\
\hline $\begin{array}{l}\text { Control of } \\
\text { brand }\end{array}$ & $\begin{array}{l}\text { We're making a conscious effort to figure what we want to } \\
\text { keep as crucial to the brand. We need to control the } \\
\text { personality of the car. We can't give away control of those } \\
\text { things." Ford, product engineering. }\end{array}$ \\
\hline $\begin{array}{l}\text { Control of } \\
\text { suppliers }\end{array}$ & $\begin{array}{l}\text { "Modules don't mean less work for the OEM. We can't } \\
\text { ignore the choice of Tier } 2 \text { and Tier } 3 \text { suppliers. We must } \\
\text { force all our suppliers to use the same metrics we do, to } \\
\text { follow the same purchasing policies that we use. We have to } \\
\text { manage all that complex coordination." Fiat, purchasing. }\end{array}$ \\
\hline Costs & $\begin{array}{l}\text { "Module builders don't make all the components - they are } \\
\text { system integrators - there's a cost associated with that." } \\
\text { Chrysler, MFG exec. }\end{array}$ \\
\hline $\begin{array}{l}\text { Knowledge } \\
\text { integration }\end{array}$ & $\begin{array}{l}\text { "Doing this right requires a high level of skills on both sides } \\
\text { [OEM and supplier]. We need to be better at the systems } \\
\text { engineering than we are... Plus the suppliers really need to } \\
\text { understand a whole lot more about the customer, the } \\
\text { warranty system, our dealers, etc. Chief engineer, Ford. }\end{array}$ \\
\hline
\end{tabular}

Table 1c. Hitting on trouble: Doubts about modularity initiatives

\begin{tabular}{|c|c|}
\hline $\begin{array}{l}\text { OEMs on } \\
\text { suppliers }\end{array}$ & $\begin{array}{l}\text { - "A lot of the claims made by suppliers about their modular capabilities are bullshit. Most will become Tier } 2 s \text {. Every type of component } \\
\text { supplier is trying to get its foot through the door." Ford, purchasing. } \\
\text { "We don't have a modulanity mindset. It may not work to take our design and build it somewhere else.... If we keep doing all the engineering. } \\
\text { we don't save anything. We may not be as good as the supplier for that component." Ford, product engineering. }\end{array}$ \\
\hline $\begin{array}{l}\text { Suppliers on } \\
\text { OEMS }\end{array}$ & $\begin{array}{l}\text { "There are mixed messages from the OEM - they want it all. If we design the module and do the tooling, the OEM still wants to control it. If } \\
\text { the customer can see it [i.e. the component], the OEM wants it kept proprietary." Supplier } 2 \text {. } \\
\text { "It's frustrating - you can have a design idea that would add value for the OEMs [which would allow supplier to charge a higher price for the } \\
\text { improved design], but they [the OEMs] won't do it." Supplier } 1 \text {. }\end{array}$ \\
\hline
\end{tabular}


Table 2a. Realigned expectations: OEMs, suppliers, and third parties

\begin{tabular}{|c|c|}
\hline OEMS & $\begin{array}{l}\text { 'The purchasing guys are losing sleep over the held hostage' scenario or over giving a module to an incompetent supplier. Ford, MFG ENG. } \\
\text { 'It's all a question of money - suppliers can't imagine spending lots of new money. The mega-suppliers] want only big volume, they want to } \\
\text { stick with processes they know. Their short-term incentive is to stay focused on components. Fiat, head of cross-plattorm component } \\
\text { development. }\end{array}$ \\
\hline Suppliers & $\begin{array}{l}\text { 'It costs } \$ 600-\$ 800 \text { million for an OEM to prove out a new platform, with all the testing and validation. We dont have those skills and we don't } \\
\text { want them. Supplier } 2 \text {. } \\
\text { "The OEMs] tell us 'don't you ty to integrate the radio and telematics - that's our expertise, not yours.' Even if they ike the design } \\
\text { improvements we offer, they dont want to take the risk of having us take over the whole package. Supplier } 3 \text {. }\end{array}$ \\
\hline $\begin{array}{l}\text { Third } \\
\text { parties }\end{array}$ & 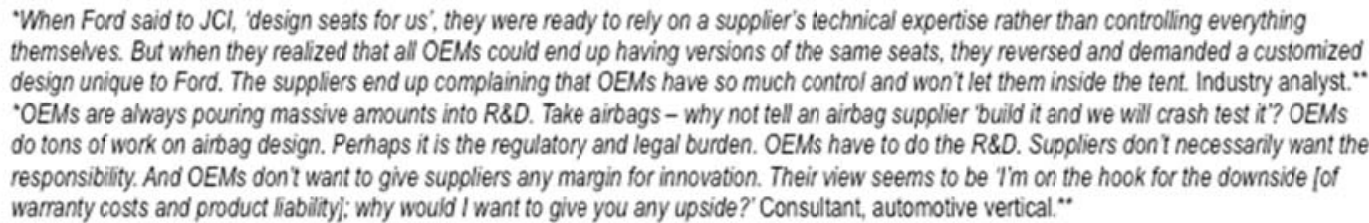 \\
\hline
\end{tabular}

Table 2b. Strategic re-think: OEMs, suppliers, and third parties

'There's no point in modulanty for its own sake. It's like Don Quixote pursuing the impossible dream. I can see why suppliers want to do it. It

OEMS brings more value.added into their plants. But despite my best intentons, / simply could n't justify doing it. Ford, Chief engineer.

"The auto industry was ready to let production go at the end of the 1990s. Since then, they have pulled back from the brink. OEMs leamed there was high risk of losing institutional knowledge that could lead to competitive problems. Economic historian."

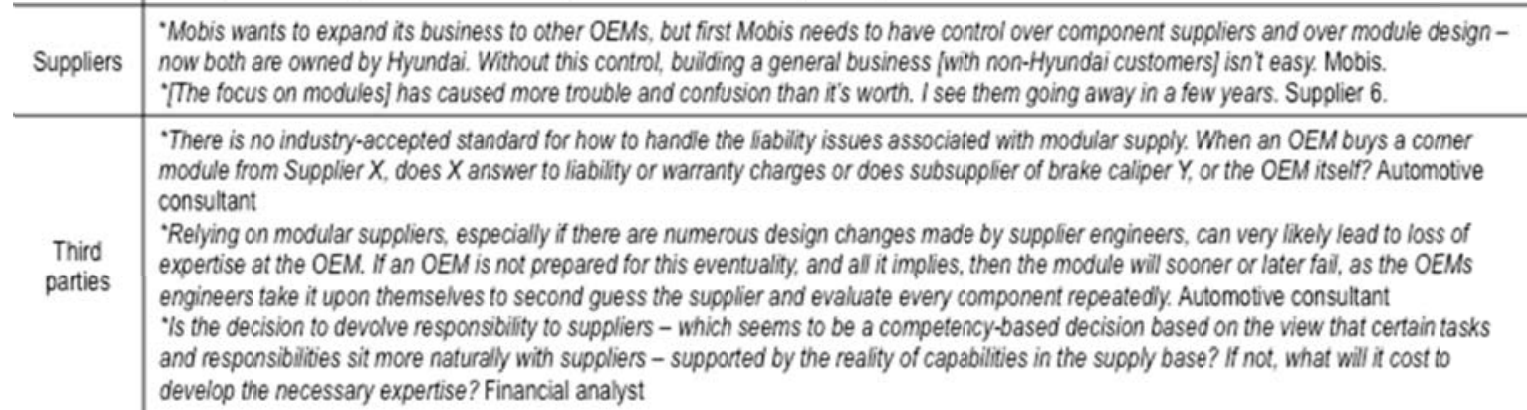

All quotes are from interviews conducted by the second author or archival sources, all between 1998 and 2003, except for:

* interviews conducted between 2003 and 2007; ** interviews with industry analysts and academic experts conducted during 2012 and 2013 
ONLINE APPENDIX

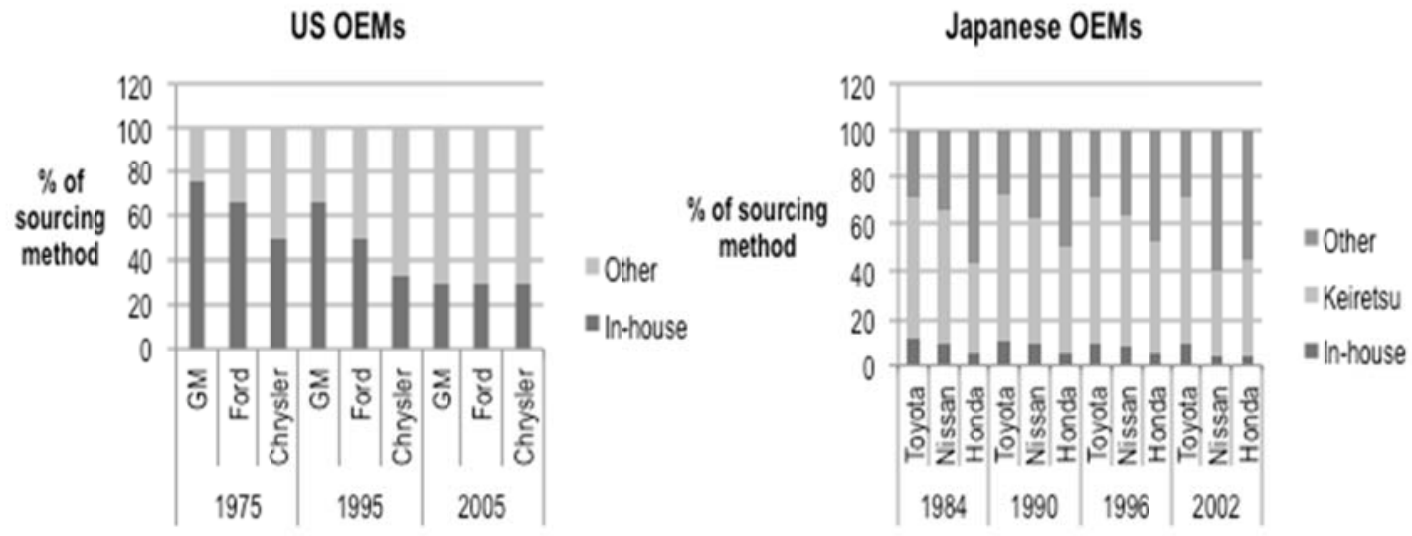

Figure A1. Differing degrees of vertical integration: U.S. OEMs vs. Japanese OEMs

Source: Adapted from MacDuffie and Helper (2006).

Note. For the US OEMs, estimates are used, which includes bought-in materials for in-house produced parts (Nishiguchi, 1994; Rubenstein, 2001). Rubenstein (2001) estimates that GM, Ford, and Chrysler levels of vertical integration were similar-around 30\%-after Delphi and Visteon spin-offs. For the Japanese OEMS, the numbers are based on IRC data on component transactions for 200 key components, analyzed by Takeishi and Noro (2005) and supplemented by Nobeoka and Manabe (2006) survey on nature of components.

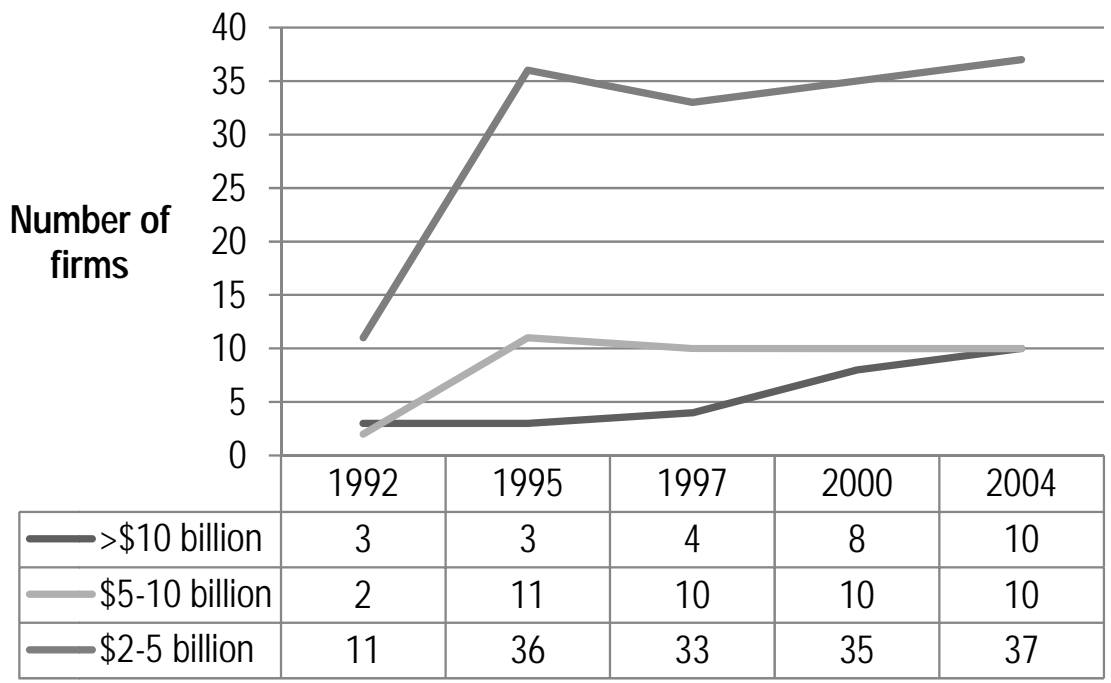

Source: Automotive News.

Figure A2. The rise of mega-suppliers, 1992-2004 
Table A1. International Motor Vehicle Program (IMVP) phases of research

\begin{tabular}{|c|l|}
\hline Period & \multicolumn{1}{|c|}{ Topics } \\
\hline $1985-1990$ & Understanding lean production \\
\hline $1992-1997$ & Diffusion and evolution of lean \\
\hline $1998-2003$ & Industry transformation? \\
\hline $2004-2007$ & Understanding persistent integrality \\
\hline $2008-2011$ & Industry crisis and recovery \\
\hline $2012-$ present & Vehicle and mobility innovations \\
\hline
\end{tabular}

Table A2. IMVP “Modularity and Outsourcing” research project, interview sites (1997-2007; most interviews conducted between 1998-2003)

\begin{tabular}{|l|l|l|}
\hline \multicolumn{1}{|c|}{ OEMs (w/ HQ country) } & \multicolumn{2}{|c|}{ Suppliers (w/ HQ country) } \\
\hline Chrysler Corporation (US) & Borg-Warner Inc. (US) & Lear (US) \\
Ford Motor Company (US) & Brose (Germany) & Magnetti Marelli (Italy) \\
General Motors (US) & Calsonic Kansei (Japan) & Mobis (Korea) \\
Hyundai Motor Corporation (Korea) & Denso (Japan) & Siemens (Germany) \\
Nissan Motor Corporation (Japan) & Faurecia (France) & Sommer Allibert (France) \\
Renault Group (France) & Federal-Mogul (US) & TRW (US) \\
Toyota Motor Company (Japan) & Johnson Controls Inc. (US) & Textron (US) \\
Volvo Car Company (Sweden) & Lames (Italy) & Toyota Gosei (Japan) \\
\hline
\end{tabular}


Table A3. Key structural characteristics of the automobile sector

\begin{tabular}{|c|c|}
\hline \multicolumn{2}{|c|}{ US Mass production industry } \\
\hline $\begin{array}{l}\text { Capital Intensive } \\
\text { - } \\
\text { Centralized R\&D; long product development cycles (4-8 years); } \\
\text { highly automated assembly plants } \\
\text { - } \quad \text { Small number of Original Equipment Manufacturers (OEMs) } \\
\text { Barier to new entrants } \\
\text { Economies of Scale } \\
\text { - } \\
\text { Premise for Henry Ford's moving assembly line } \\
\text { - } \quad \text { Gives OEMs bor low price of mass produced cars } \\
\text { - Each OEM has sufficiently high volume to surpass minimal } \\
\text { efficient scale for proprietary components }\end{array}$ & $\begin{array}{l}\text { High \% of Vertical integration (VI) } \\
\text { - } \quad \text { Near } 100 \% \text { under Henry Ford (1910-1930); also high at GM } \\
\text { and Chrysler after industry consolidation in 1930s } \\
\text { - } \quad 50-75 \% \text { after WWII; still } 35-50 \% \text { in 1980s } \\
\text { OEM Roles and Responsibilities } \\
\text { - } \quad \text { OEMs are system integrators } \\
\text { - } \quad \text { OEMs control brand differentiation, marketing, and sales } \\
\text { - } \quad \text { Vehicles sold, maintained through franchise dealerships } \\
\text { - } \quad \text { OEMs have regulatory responsibility for safety, emissions, } \\
\text { fuel efficiency; also initiate and manage recalls } \\
\text { - OEMs bear legal liability; suppliers do not since OEM puts all } \\
\text { parts together (MacPherson v. Buick Motor Co., 1916) }\end{array}$ \\
\hline Product architecture & Global similarities \& differences \\
\hline $\begin{array}{l}\text { - Dominant design established in } 1920 \text { s and hasn't changed up to } \\
\text { present } \\
\text { - Innovation in components and systems rather than in } \\
\text { fundamental architecture } \\
\text { - High interdependence among systems and components in } \\
\text { physical proximity } \\
\text { - Many systemic attributes important to end users, e.g. "look and } \\
\text { feel"; noise, vibration, and harshness (NVH); wind noise; } \\
\text { handling; etc. } \\
\text { - Fast, heavy, dangerous, operated in public space; hence highly } \\
\text { regulated }\end{array}$ & $\begin{array}{l}\text { - Vertical integration lower in Europe than in U.S.; } \\
\text { - VI much lower in Japan, i.e. } 10-20 \% \text { in post WWII period up to } \\
\text { present } \\
\text { - Japanese OEMs create keiretsu, i.e. groups of suppliers with } \\
\text { interlocking equity stakes } \\
\text { - Japanese OEMs collaborate on design with keiretsu suppliers } \\
\text { via quasi-VI org processes } \\
\text { - Korean OEMs are similar to Japanese OEMs with suppliers } \\
\text { part of corporate chaebol } \\
\text { - OEMs have similar roles vis-à-vis system integration, } \\
\text { brand/marketing/sales worldwide } \\
\text { - Franchise dealerships common worldwide } \\
\text { - All developed countries put regulations on safety, emissions, } \\
\text { fuel efficiency etc. in place w/OEMs as responsible party }\end{array}$ \\
\hline
\end{tabular}


Table A4: [Complements Table 1a] Shared strategic vision for modularity + outsourcing (initiated by OEMs, who define the new roles and responsibilities; accepted by suppliers, who are searching for opportunities; encouraged by third parties)

\begin{tabular}{|c|c|}
\hline $\begin{array}{c}\text { OEM } \\
\text { advocates }\end{array}$ & $\begin{array}{l}\text { "Core competence" rationale } \\
\text { "Modules should get us to the next level- how to design and build a vehicle quicker, better, cheaper, closer to what customers want. If we } \\
\text { do modules right, it will change how we think about building the vehicle and it will put the expertise where it should be, in the supply } \\
\text { base... I don't see that very many of the component things we do are 'core'. We're buying engines from PSA, transmissions from ZF, } \\
\text { electronics from Visteon. I don't see anything that we're not willing to outsource. We should be focused on system engineering and } \\
\text { standards." Ford, corporate strategy. } \\
\text { "The main strategy of Fiat is value creation. The goal of module sourcing is to focus on our core competence... We started with ... } \\
\text { internal modules. Now we want to focus on core competence and we are trying to outsource the modules." Fiat, purchasing. } \\
\text { Advantages seen from supplier autonomy, focus, and responsibility } \\
\text { "We should give suppliers a target price and say 'you figure out how to make it.' They should have an advantage in terms of focus. } \\
\text { Suppliers could join together to assemble the final module as we've defined it." Ford, product engineering. }\end{array}$ \\
\hline $\begin{array}{c}\text { Supplier } \\
\text { advocates }\end{array}$ & $\begin{array}{l}\text { Advantages seen from supplier component knowledge, autonomy, and integration capabilities } \\
\text { "Integration means the ability to remove chimney organizations -- where responsibilities are organized by components --and replace them } \\
\text { with a team that looks at the module as one unit. Suppliers are better able to do this because OEMs don't have the same depth of } \\
\text { knowledge." Supplier } 1 \text {, product engineering. } \\
\text { "The opportunity for us is to get the chance to manage all of this - to take charge of the customizing based on our understanding of what } \\
\text { each customer needs." Supplier 2, product engineering. }\end{array}$ \\
\hline $\begin{array}{l}\text { Third party } \\
\text { advocates }\end{array}$ & $\begin{array}{l}\text { Financial performance benefits } \\
\text { "As the automotive industry moves towards modularization - with suppliers acting as integrators rather than pure manufacturers - we } \\
\text { would expect RolC to improve from current levels. This is because module production, though a lower margin business, ties up less } \\
\text { capital than traditional component manufacturing." Goldman Sachs Auto Equity } \\
\text { Necessity given already-increased reliance on suppliers } \\
\text { "Carmakers the world over are seeking more and more input and assistance from their suppliers. First, OEMs realize that they gain } \\
\text { immensely by cutting back on the number of suppliers translates into their asking each of the remaining few to pick up more duties. } \\
\text { Second, OEMs realize that suppliers have more to offer in terms of component know-how than OEMs have tapped thus far. Suppliers, in } \\
\text { turn, hope to grow faster, boost profits, and gain stability." Economist Intelligencer Unit } \\
\text { Standardization: "The most important potential benefit of modularity is standardization, allowing suppliers to offer standard solutions to } \\
\text { different OEMs and hence bring costs down. For the supplier, the added responsibility for design and development brings new } \\
\text { opportunities." Aroq Limited for just-auto.com }\end{array}$ \\
\hline
\end{tabular}


Table A5. [Complements Table 1b] Framing contests within OEMs: Debates over potential problems from expanding supplier roles and responsibilities

\begin{tabular}{|c|c|}
\hline Problems unless OEMs select capable suppliers & $\begin{array}{l}\text { Problems from increased costs associated with suppliers taking on more } \\
\text { responsibility }\end{array}$ \\
\hline $\begin{array}{l}\text { "We're now having the suppliers come in to tell us what their capabilities are. } \\
\text { We want to be able to certify that a supplier is module-ready. They need lots of } \\
\text { project management skills. We expect them to manage the Tier } 2 \text { and Tier } 3 \\
\text { suppliers as well. They'll have to do all the certification that we do, e.g. they'll } \\
\text { have to be able to test for wind noise the same way we would, meet all of our } \\
\text { requirements." Ford, product engineering. } \\
\text { With a module, you aren't just buying [from a supplier] something you } \\
\text { understand, like a component, but the capacity to do something, namely to } \\
\text { design and integrate to meet our requirements." Fiat, head of cross-platform } \\
\text { component development. }\end{array}$ & $\begin{array}{l}\text { "When you're designing a whole set of parts brought together through } \\
\text { geographic proximity, you need to understand every interface deeply. This } \\
\text { could add lots of time and cost." Chief engineer, Ford. } \\
\text { "Module builders don't make all the components - they are system integrators } \\
\text { - there's a cost associated with that." Chrysler, manufacturing executive. }\end{array}$ \\
\hline $\begin{array}{l}\text { Problems unless OEMs stay in control of differentiation, integration, and } \\
\text { coordination }\end{array}$ & $\begin{array}{l}\text { Problems unless OEMs and suppliers learn *a lot *about what the other } \\
\text { party does }\end{array}$ \\
\hline $\begin{array}{l}\text { "We're making a conscious effort to figure what we want to keep as crucial to } \\
\text { the brand. We need to control the personality of the car. We can't give away } \\
\text { control of those things." Ford, product engineering. } \\
\text { "When [a GM senior executive] was recently asked, 'How can you best } \\
\text { differentiate?' his answer wasn't 'drive train'- instead he said 'vehicle validation } \\
\text { and integration is where we differentiate." Financial analyst. } \\
\text { "Modules don't mean less work for the OEM. We can't ignore the choice of } \\
\text { Tier } 2 \text { and Tier } 3 \text { suppliers. We must force all our suppliers to use the same } \\
\text { metrics we do, to follow the same purchasing policies that we use. We have to } \\
\text { manage all that complex coordination." Fiat, purchasing. }\end{array}$ & $\begin{array}{l}\text { "Doing this right requires a high level of skills on both sides [OEM and supplier] } \\
\text { and we're just coming to grips with that. We at Ford need to be better at the } \\
\text { systems engineering than we are.... Plus the suppliers really need to } \\
\text { understand a whole lot more about the customer, the warranty system, our } \\
\text { dealers, etc. Chief engineer, Ford. } \\
\text { "We have a lot of useful overlap in knowledge. Thirty to } 40 \text { percent of our } \\
\text { engineers come from Hyundai, with lots of experience in car design. This } \\
\text { makes communication with the OEM design engineers easy. The remaining } 60 \\
\text { to } 70 \text { percent of our engineers are from component manufacturers. This helps } \\
\text { us understand both sides-vehicle and component. Hyundai's system } \\
\text { engineering capability is good, but they don't know the details of components. } \\
\text { Mobis engineers can provide this knowledge linking." Product engineering, } \\
\text { Mobis (Hyundai-owned supplier). }\end{array}$ \\
\hline
\end{tabular}


Table A6. [Complements Table 1c] Hitting on trouble—doubts about modularity initiatives, OEMs and suppliers

\begin{tabular}{|c|c|}
\hline \multicolumn{2}{|c|}{ OEMs } \\
\hline Doubts on supplier capabilities & Doubts on gains from modularity \\
\hline $\begin{array}{l}\text { "It's not clear whether there are suppliers with all the capabilities we need for } \\
\text { integrated modules.... We have very few full service suppliers. Plus we have } \\
\text { some lousy suppliers. But we're a crutch for them..... The suppliers have got } \\
\text { to figure out who's going to excel and get rid of the crutches. Most are reluctant } \\
\text { to invest in what we need from them. We're trying to force suppliers to } \\
\text { consolidate or they lose our business." Ford, corporate strategy. } \\
\text { "A lot of the claims made by suppliers about their modular capabilities are } \\
\text { bullshit. Most will become Tier } 2 s \text {. Every type of component supplier is trying to } \\
\text { get its foot through the door." Ford, purchasing. } \\
\text { "Suppliers are backsliding, some of their quality is atrocious. The Tier } 1 s \text { don't } \\
\text { understand process control, and they're not coordinating the lower tiers. The } \\
\text { problem gets bigger and bigger as you give them more responsibility. They are } \\
\text { struggling." Chrysler, manufacturing. }\end{array}$ & $\begin{array}{l}\text { "We don't have a modularity mindset. It may not work to take our design } \\
\text { and build it somewhere else.... If we keep doing all the engineering, we } \\
\text { don't save anything. We may not be as good as the supplier for that } \\
\text { component." Ford, product engineering. } \\
\text { "lt's all a question of money - suppliers can't imagine spending lots of new } \\
\text { money. [The mega-suppliers] want only big volume, they want to stick with } \\
\text { processes they know. Their short-term incentive is to stay focused on } \\
\text { components." Fiat, head of cross-platform component development. } \\
\text { "Our plant people don't believe that the suppliers can do it better than them. } \\
\text { If our internal cost is equal or better than a supplier's cost, we bring it in- } \\
\text { house. That's the only fair thing to do vis-à-vis the workforce." Ford, } \\
\text { manufacturing engineering. }\end{array}$ \\
\hline \multicolumn{2}{|c|}{ Suppliers } \\
\hline Doubts on OEM intentions & Doubts on gains from modularity \\
\hline $\begin{array}{l}\text { "There are mixed messages from the OEM - they want it all. If we design the } \\
\text { module and do the tooling, the OEM still wants to control it. If the customer } \\
\text { can see it [i.e. the component], the OEM wants it kept proprietary." Supplier } 2 . \\
\text { "It's frustrating - you can have a design idea that would add value for the } \\
\text { OEMs [which would allow supplier to charge a higher price for the improved } \\
\text { design], but they [the OEMs] won't do it." Supplier } 1 . \\
\text { "If the OEM just hands us a module, we can't save them anything except a bit } \\
\text { on labor. The integration opportunity requires that we have control of Tier } 2 \\
\text { suppliers. Ford wants us to do a module, then says 'you need to use this wiring } \\
\text { supplier for everything'." Supplier } 8\end{array}$ & $\begin{array}{l}\text { "We work with over } 60 \text { different electrical connector designs. We could } \\
\text { easily do all of our designs with just 6-10 connector types, but the OEMs } \\
\text { won't approve them. We need to hold some very high level meetings with } \\
\text { the OEMs to push them to use standardized components." Supplier } 1 . \\
\text { "If we acquire to have many components and be able to do modules, that } \\
\text { doesn't mean that we can integrate those components successfully. } \\
\text { Ownership may mean quicker decisions, but it may not lead to better } \\
\text { integration." Supplier } 7 .\end{array}$ \\
\hline
\end{tabular}


Table A7. [Complements Table 2a] Realigned expectations at OEMs, given worry about uncertain gains, control issues, difficulty in shifting roles and responsibilities

\begin{tabular}{l} 
Worry about uncertain gains \\
"The purchasing guys are losing sleep over the 'held hostage' scenario or over giving a module to an incompetent supplier." Ford, \\
manufacturing engineering. \\
\hline Control issues \\
"OEMs definitely believe that they need differentiability throughout the vehicle. I believe it too, but I think the OEMs overstate it. When \\
themselves. But when they realized that all OEMs could end up having versions of the same seats, they reversed and demanded a \\
customized design unique to Ford. The suppliers end up complaining that OEMs have so much control and won't let them inside the \\
tent." Industry analyst. \\
\hline Difficulty in shifting roles and responsibility "OEMs are always pouring massive amounts into R\&D. Take airbags - why not tellan \\
airbag supplier 'build it and we will crash test it'? OEMs do tons of work on airbag design. Perhaps it is the regulatory and legal burden. \\
OEMs have to do the R\&D. Suppliers don't necessarily want the responsibility. And OEMs don't want to give suppliers any margin for \\
innovation. Their view seems to be 'I'm on the hook for the downside [of warranty costs and product liability]; why would I want to give \\
you any upside?"' Consultant, automotive vertical.
\end{tabular}

Table A8. [Complements Table 2a] Realigned expectations at suppliers, given realization of structural barriers

\begin{tabular}{|c|}
\hline \\
\hline $\begin{array}{l}\text { Control barrier re: OEM system integrator role } \\
\text { "[The OEMs] tell us 'don't you try to integrate the radio and telematics -- that's our expertise, not yours.' Even if they like the design } \\
\text { improvements we offer, they don't want to take the risk of having us take over the whole package." Supplier } 3 \text {. }\end{array}$ \\
\hline $\begin{array}{l}\text { Regulatory and liability barrier re: supplier wish to avoid responsibility } \\
\text { "When Intel began to advertise 'Intel Inside', that boosted Intel's profits. Would 'Bosch Inside' or 'Delphi Inside' help bring in more profit? } \\
\text { Would consumers really notice? More likely we would look like an upstart - getting more attention from the media - more lawsuits. Right } \\
\text { now, the OEM has to deal with product liability lawsuits. We would prefer to avoid that. If you open the door to being a rival with the OEM, } \\
\text { you are opening the door to being asking to take full legal responsibility for product failures." Supplier } 4 .\end{array}$ \\
\hline
\end{tabular}


Table A9. [Complements Table 2b] Strategic rethink: OEMs calling the shots; suppliers skeptical of benefits; third parties detect strategic risks

\begin{tabular}{|c|c|}
\hline $\begin{array}{l}\text { OEMs: Ready to } \\
\text { retract from } \\
\text { modularity }\end{array}$ & $\begin{array}{l}\text { "There's no point in modularity for its own sake. It's like Don Quixote pursuing the impossible dream. I can see why suppliers want to do } \\
\text { it. It brings more value-added into their plants. But despite my best intentions, I simply couldn't justify doing it." Chief engineer, Ford. } \\
\text { "The auto industry was ready to let production go at the end of the } 1990 \text { s. Since then, they have pulled back from the brink. OEMs } \\
\text { learned there was high risk of losing institutional knowledge that could lead to competitive problems." Economic historian. }\end{array}$ \\
\hline $\begin{array}{l}\text { Suppliers: } \\
\text { Skeptical about } \\
\text { modularity offering } \\
\text { them benefits }\end{array}$ & $\begin{array}{l}\text { "Mobis wants to expand its business to other OEMs, but first Mobis needs to have control over component suppliers and over module } \\
\text { design - now both are owned by Hyundai. Without this control, building a general business [with non-Hyundai customers] isn't easy.." } \\
\text { Mobis, Hyundai-owned supplier. } \\
\text { "[The focus on modules] has caused more trouble and confusion than it's worth. I see them going away in a few years." Supplier } 6\end{array}$ \\
\hline $\begin{array}{l}\text { Third parties: } \\
\text { Seeing strategic } \\
\text { risks in modularity }\end{array}$ & $\begin{array}{l}\text { "There is no industry-accepted standard for how to handle the liability issues associated with modular supply. When an OEM buys a } \\
\text { cormer module from Supplier X, does X answer to liability or warranty charges or does subsupplier of brake caliper Y, or the OEM itself?" } \\
\text { Automotive consultant } \\
\text { "Relying on modular suppliers, especially if there are numerous design changes made by supplier engineers, can very likely lead to loss } \\
\text { of expertise at the OEM. If an OEM is not prepared for this eventuality, and all it implies, then the module will sooner or later fail, as the } \\
\text { OEMs engineers take it upon themselves to second guess the supplier and evaluate every component repeatedly." Automotive } \\
\text { consultant } \\
\text { "Is the decision to devolve responsibility to suppliers - which seems to be a competency-based decision based on the view that certain } \\
\text { tasks and responsibilities sit more naturally with suppliers - supported by the reality of capabilities in the supply base? If not, what will it } \\
\text { cost to develop the necessary expertise?" Financial analyst }\end{array}$ \\
\hline
\end{tabular}

All quotes are from interviews conducted by the second author or archival sources, all between 1998 and 2003, except for:

* interviews conducted between 2003 and 2007; ** interviews with industry analysts and academic experts conducted during 2012 and 2013. 